\title{
PERFIL TECNOLÓGICO DOS FORNECEDORES DE CANA-DE- AÇÚCAR E ENTRAVES PARA A ADOÇÃO DE SISTEMAS AGROFLORESTAIS NA REGIÃO DE PIRACICABA, SP - BRASIL
}

\author{
NORMA VIRGINIA MIGONE SEGOVIA
}

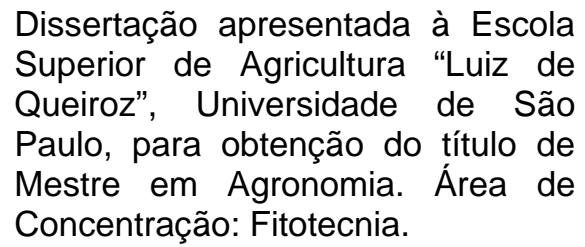

PIRACICABA

Estado de São Paulo - Brasil

Fevereiro - 2004 


\title{
PERFIL TECNOLÓGICO DOS FORNECEDORES DE CANA-DE- AÇÚCAR E ENTRAVES PARA A ADOÇÃO DE SISTEMAS AGROFLORESTAIS NA REGIÃO DE PIRACICABA, SP - BRASIL
}

\author{
NORMA VIRGINIA MIGONE SEGOVIA
}

Engenheiro Agrônomo

Orientador: Prof. Dr. MARCOS SILVEIRA BERNARDES

Dissertação apresentada à Escola
Superior de Agricultura "Luiz de
Queiroz", Universidade de São
Paulo, para obtenção do título de
Mestre em Agronomia. Área de
Concentração: Fitotecnia.

PIRACICABA

Estado de São Paulo - Brasil

Fevereiro - 2004 


\section{Migone Segovia, Norma Virginia}

Perfil tecnológico dos fornecedores de cana-de-açúcar e entraves para a adoção de sistemas agroflorestais na região de Piracicaba, SP - Brasil / Norma Virginia Migone Segovia. - - Piracicaba, 2004

$90 \mathrm{p}$.

Dissertação (mestrado) - - Escola Superior de Agricultura Luiz de Queiroz, 2004. Bibliografia.

1. Cana-de-açúcar 2. Colheita mecânica 3. Fornecedor 4. Legislação ambiental 5. Sistemas agroflorestais 6 . Tecnologia agrícola I. Título 


\section{Dedicatória}

O Senhor é meu pastor, nada me falta.

A meus pais Héctor, Gladys e meu irmão Luis

Enrique, que sempre apoiaram minhas decisões

com respeito e carinho, e ainda longe acompanham

sempre meu caminho.

A meus avós, Nene, Nina, María e Alberto,

e a todos meus familiares, pelas tradições

conservadas ao longo do tempo com a mesma força e alegría de sempre.

DEDICO

Ao Amor e à amizade que chegam no momento certo, para compartilhar esta etapa importante da minha vida e ajudar na superação das dificuldades.

\section{OFEREÇO}




\section{AGRADECIMENTOS}

Ao Prof. Dr. Marcos Silveira Bernardes (Gabi), pela invalorável amizade e ensinamentos na orientação como estudante, no trabalho de pesquisa, e principalmente ao facilitar minha adaptação como estudante estrangeira no Brasil.

Aos professores do Departamento de Economia e Sociologia Rural Dalcio Caron e Oriowaldo Queda da ESALQ/USP, que ajudaram co-orientando o trabalho. Ao Prof. Dr. Moacir Darolt, do Instituto Agronômico do Paraná (IAPAR), pela colaboração com os questionários. Ao Prof. Dr. Cleimon Eduardo do Amaral Dias, do CAV da UDESC, pelas sugestões e correções preliminares do trabalho.

Á AFOCAPI, especialmente aos colegas e amigos Marcos, Márcia, Eduardo, Nelson e Benedito, pelo apoio fundamental para conhecer a realidade dos fornecedores de cana e na coleta de dados.

Ao Ministerio de Agricultura y Ganadería da República do Paraguai, especificamente à Dirección de Investigación Agrícola, pelo licenciamento que permitiu a participação no curso e mantendo o vínculo empregatício.

Á Universidade de São Paulo, Escola Superior de Agricultura "Luiz de Queiroz", Curso de Pós-Graduação em Fitotecnia, representado pelo Prof. Dr. Durval Dourado Neto, pela seleção como aluna estrangeira. 
Ao Departamento de Produção Vegetal, especialmente aos professores Ricardo Vitória Filho, Pedro Christtoffoletti, Gil M. S. Câmara, Ederaldo Chiavegato, Edgar de Beauclair, pelo incentivo na procura de novos conhecimentos. Aos colaboradores Ivete, Luciane, Silvia, Aparecida, Bette, Célia e Tino pela amizade e ajuda no dia a dia na parte burocrática e logística.

À bibliotecária Silvia Zinsly, da seção de referências da DIBD, pelas ágeis correções do trabalho. A todos os funcionários das Bibliotecas da ESALQ, pela atenção nas consultas realizadas.

Aos meus colegas e amigos: Valéria e Juan, María e Jorge, Nicolás e Verónica, Ramón, Alice, Pablo e Mary, Cecilia e Axel, Rosa e Vanolí, Cristina, Carol, Silvia, Aline, Luciano, Daniela, Márcio, Fuji, Miriam, Márcia, Eduardo, Carlos, Cristiane, Leila, Aureny, Cássia, Ciro, Paquinha, Tanaka, Mônica, e Lilia, pela amizade e pelo companheirismo, naqueles inesquecíveis momentos vividos.

A todos os que de alguma maneira apoiaram e contribuíram com o início e a ansiada finalização desta difícil aventura na Pós-Graduação, o mais sincero agradecimento. 


\section{SUMÁRIO}

Página

RESUMO

SUMMARY

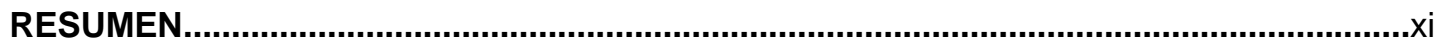

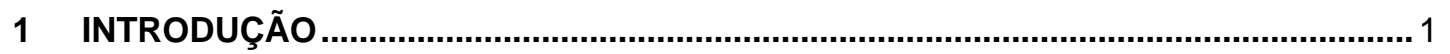

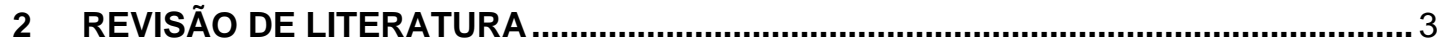

2.1 Situação atual do setor canavieiro brasileiro, paulista e piracicabano. .............................. 3

2.2 Como a legislação atual afeta os fornecedores de cana ................................................... 8

2.3 Mudanças no sistema de produção da cana-de-açúcar ................................................. 13

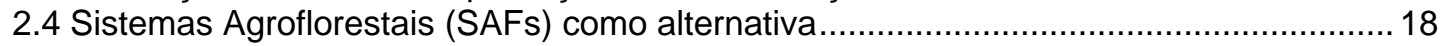

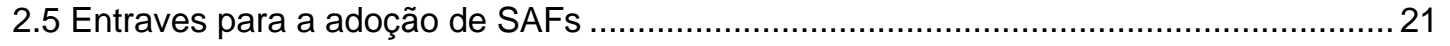

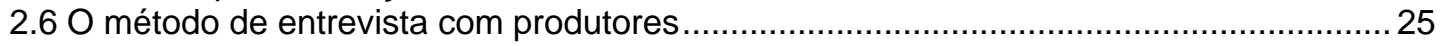

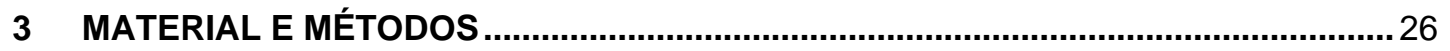

3.1 Sistema de produção da cana-de-açúcar ................................................................... 28

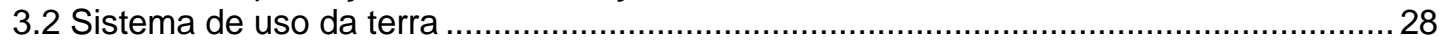

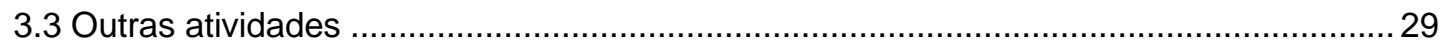

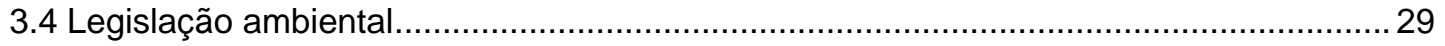

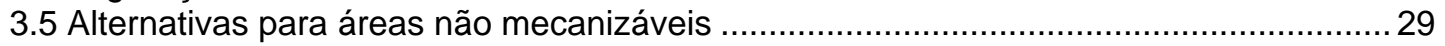

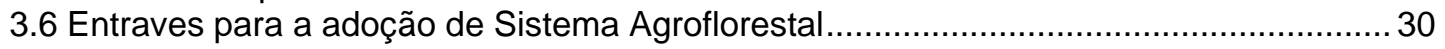

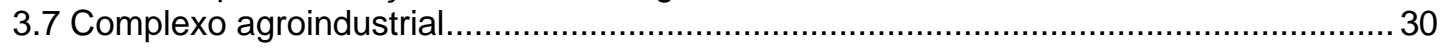

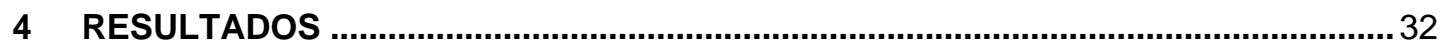

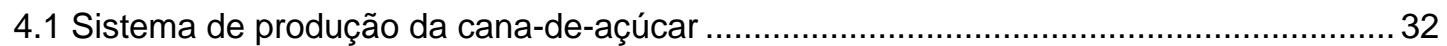

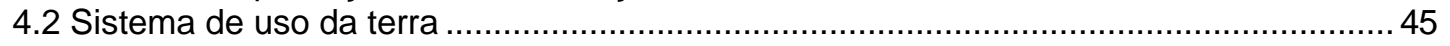

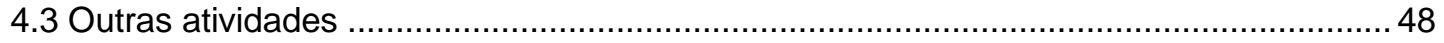

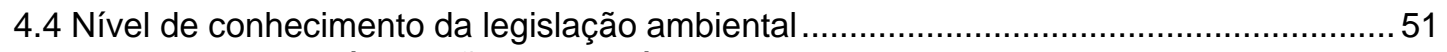

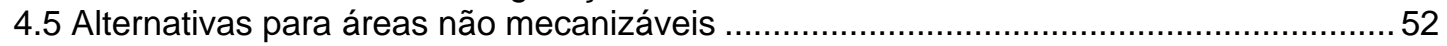

4.6 Entraves para a adoção de Sistemas Agroflorestal ...................................................... 52

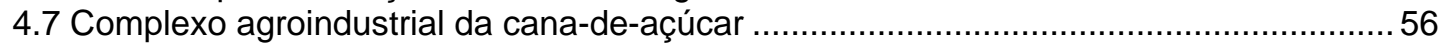

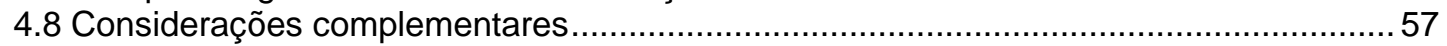

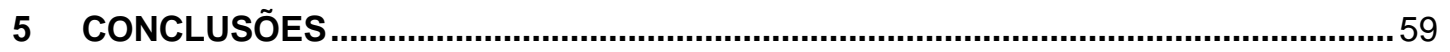

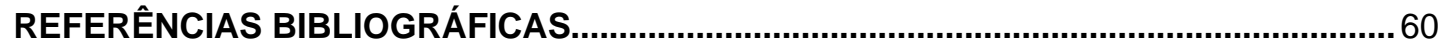

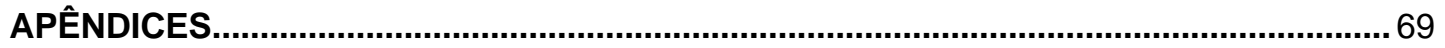




\title{
PERFIL TECNOLÓGICO DOS FORNECEDORES DE CANA-DE-AÇÚCAR E ENTRAVES PARA A ADOÇÃO DE SISTEMAS AGROFLORESTAIS NA REGIÃO DE PIRACICABA, SP - BRASIL
}

\author{
Autora: NORMA VIRGINIA MIGONE SEGOVIA \\ Orientador: Prof. Dr. MARCOS SILVEIRA BERNARDES
}

\section{RESUMO}

A legislação atual exige adequações no sistema de produção da canade-açúcar, proibindo gradativamente a queima como método de despalha antes do corte, com o que a colheita deve ser com corte manual ou mecanizado. $37 \%$ das terras da região de Piracicaba apresentam declividade acima de 12\%, o que dificulta a mecanização da colheita. Os sistemas agroflorestais (SAFs) apresentam potencial para manter a atividade agrícola na região de Piracicaba, dando maior sustentabilidade ao setor sucroalcooleiro. Através de visitas às unidades fornecedoras da região de Piracicaba, foram realizadas entrevistas com fornecedores de cana-de-açúcar, 25 em total, 7 em Rio das Pedras, 10 em Charqueada, 6 em Iracemápolis e 2 em Ipeúna, que trabalham em área própria e têm a atividade canavieira como principal, cadastrados na Associação de Fornecedores de Cana de Piracicaba (AFOCAPI), nos meses de abril e maio de 2002. Os questionários foram elaborados em base naqueles de Caron (1986) e Darolt (2000), considerando indicadores relacionados com a adoção de 
Sistemas Agroflorestais. Verifica-se o desconhecimento sobre SAFs. Entretanto, quando alertados das vantagens desses sistemas, os fornecedores se interessam pelas possibilidades de aproveitar melhor as áreas declivosas com SAFs. Também, não demonstra resistência natural à mudança tecnológica. Os entraves para a adoção, não são intrínsecos aos fornecedores, mas são principalmente devido às características da própria tecnologia como a adaptabilidade da tecnologia às condições locais, a segurança do mercado para os produtos e a falta de um programa oficial de assistência técnica. Os fornecedores podem investir, desde que a alternativa tecnológica seja rentável. Porém, tem uma aversão ao risco financeiro para investimentos a longo prazo. Dessa forma, o principal impedimento para a adoção de SAFs é a ausência de comprovação concreta das vantagens agronômicas e econômicas desses sistemas. 


\title{
SUGARCANE SMALL GROWERS TECHNOLOGICAL PROFILE AND THE RESTRAINT FOR ADOPTION OF AGROFORESTRY SYSTEMS IN PIRACICABA REGION, SP - BRAZIL
}

\author{
Author: NORMA VIRGINIA MIGONE SEGOVIA \\ Advisor: Prof. Dr. MARCOS SILVEIRA BERNARDES
}

\section{SUMMARY}

Present legislation in Brazil, by gradually preventing the sugarcane burnt, provoke adjustments on the production system, mainly by changing the harvest process from that done by labor to mechanized cutting and collection of the stalks. In the region of Piracicaba $37 \%$ of the land has an slope of $12 \%$ or above, what makes mechanization very difficult. Agroforestry systems (AFSs) have the potential to preserve the agriculture activity in the region of Piracicaba, improving the sustainability of sugarcane production chain. Sugarcane small growers, who cultivate their own land, and have the sugarcane as their main crop and were associated to the regional growers association (AFOCAPI) were visited and interviewed, 25 in total, being 7 in Rio das Pedras., 10 in Charqueada, 6 in Iracemápolis and 2 in Ipeúna sub-regions. A questionnaire, considering indicators related to the adoption of SAFs. It was observed a nonacquaintance about AFSs. However, when warned about the advantages of these systems, growers are interested about the possibilities of better utilize the undulating and steep areas with AFSs. Besides, they do not demonstrate natural 
opposition to technological changes. Restraint for adoption are not intrinsic to growers but mainly due to the characteristics of the technology itself, as the adaptability of technology to local conditions, the market safety for their products, and the inexistence of a official program of technical assistance. Growers may invest, since the alternative technology is profitable. Nevertheless, the have aversion to financial risk for long term investments. Thus, the major restraint for adoption of AFSs is the inexistence of concrete confirmation of the agronomical and economical advantages of these production systems. 


\title{
PERFIL TECNOLÓGICO DE LOS CAÑICULTORES Y DIFICULTADES PARA LA ADOPCIÓN DE SISTEMAS AGROFORESTALES EN LA REGIÓN DE PIRACICABA, SP - BRASIL
}

\author{
Autora: NORMA VIRGINIA MIGONE SEGOVIA \\ Orientador: Prof. Dr. MARCOS SILVEIRA BERNARDES
}

\section{RESUMEN}

La legislación actual exige adecuaciones en el sistema de producción da la caña de azúcar, prohibiendo gradualmente la quema antes del corte, con lo que la cosecha debe realizarse manual o mecánicamente. El $37 \%$ de las tierras de la región de Piracicaba tienen una pendiente superior al 12\%, lo que dificulta la mecanización de la cosecha. Los Sistemas Agroforestales (SAFs) tienen un gran potencial para mantener la actividad agrícola en la región de Piracicaba, dando mayor sostenibilidad al sector agrio-industrial de la caña de azúcar. En visitas a unidades productoras de la región de Piracicaba, fueron realizadas entrevistas con cañicultores, 25 en total, 7 en Río das Pedras, 10 en Charqueada, 6 en Iracemápolis e 2 en Ipeúna, que trabajan en área propia y tienen a la actividad cañera como principal, censados en la Asociación de Cañicultores de Piracicaba (AFOCAPI), entre los meses de abril y mayo de 2002. Los cuestionarios fueron elaborados en base a los de Caron (1986) y Darolt (2000), considerando indicadores relacionados con la adopción de Sistemas Agroforestales. Se comprobó la falta de conocimiento sobre SAFs. 
Entretanto, cuando fueron informados de las ventajas de esos sistemas, los cañicultores se interesaron debido a las posibilidades de aprovechar mejor las áreas con pendiente. No demostraron resistencia natural a los cambios tecnológicos. Las dificultades para la adopción no son intrínsecos a los cañicultores, pero son principalmente debido a las características de la propia tecnología, como su adaptabilidad a las condiciones locales, la seguridad del mercado para los productos y la falta de un programa oficial de asistencia técnica. Los cañicultores pueden invertir, siempre que la alternativa tecnológica sea rentable. Tienen un cierto rechazo a las inversiones a largo plazo, debido al riesgo financiero. La principal barrera para la adopción de SAFs, es la falta de una información comprobada y concreta, de las ventajas agronómicas y económicas de estos sistemas. 


\section{INTRODUÇÃO}

O setor sucroalcooleiro brasileiro passou recentemente por uma desregulamentação do mercado de cana-de-açúcar e seus produtos, associada com a extinção pelo governo federal de mecanismos de apoio à lavoura canavieira e às usinas e destilarias. Esse recuo do governo coincidiu temporalmente com o crescimento da pressão por melhoria das condições ambientais pela sociedade brasileira. A legislação atual, principalmente aquela de cunho ambiental, modificou substancialmente o cenário, criando restrições que provocaram modificações no sistema produtivo. Entretanto, a longa história da cultura da cana-de-açúcar no país atravessando diversos revezes e crises das mais diferentes naturezas, conferiu aos agentes da cadeia produtiva um comportamento conservador, que retarda a tomada de decisões para a adoção de modificações no sistema produtivo. Os sistemas agroflorestais (SAFs) são formas de uso da terra que foram revitalizadas na agricultura, e sua implantação implica na adoção de modificações fundamentais no sistema de produção de monocultivo hora adotado no setor canavieiro, porém, que podem trazer algumas soluções para as limitações impostas pela legislação. Neste sentido, identificar o nível e o perfil tecnológico e as práticas em uso pelos fornecedores, diagnosticar o nível de conhecimento das exigências da legislação ambiental para o setor sucroalcooleiro, categorizar e dimensionar os entraves para a adoção dos SAFs são alguns dos passos iniciais para a implementação de novos sistemas produtivos que beneficiem aos fornecedores de cana-de-açúcar e à sociedade de entorno e que permitam a continuidade da 
lavoura canavieira na região de Piracicaba-SP, sendo esses os objetivos do presente estudo. As hipóteses da pesquisa são de que:

a) os fornecedores de cana-de-açúcar da região de Piracicaba desconhecem a alternativa de produção em sistemas agroflorestais visando atender as demandas da legislação ambiental;

b) existe resistência natural à mudança tecnológica, principalmente sem demonstração empírica local com resultados positivos;

c) mesmo que o indivíduo acredite no sistema agroflorestal como alternativa para manter a cultura da cana-de-açúcar em áreas com restrições para mecanização da colheita, os principais impedimentos para a adoção são os elevados custo inicial e o risco financeiro. 


\section{REVISÃO DE LITERATURA}

O entendimento do panorama do setor canavieiro, na escala mundial, nacional, estadual e regional é crucial para qualquer aprimoramento da cadeia produtiva. Faz parte desse entendimento, conhecer-se em detalhes a legislação ambiental que enfocou principalmente a atividade de queima da cana e a recuperação de reservas florestais e como essa legislação provocou a necessidade de mudanças no sistema produtivo. Os SAFs, como sistemas de produção alternativos para enfrentar os desafios de mudança, precisam ser descritos e adaptados às particularidades da lavoura canavieira, e sua adoção provavelmente sofre impedimentos que passam pelas barreiras culturais dos fornecedores e pela ausência de tecnologia apropriada devidamente testada e difundida.

\subsection{Situação atual do setor canavieiro brasileiro, paulista e piracicabano.}

A importância da lavoura da cana-de-açúcar no Brasil é amplamente reconhecida. Foi a primeira cultura a ser explorada comercialmente no Brasil. Segundo Ramos (1999), os portugueses precisavam de produtos para abastecer as novas colônias, produzindo suprimentos para os mercados metropolitanos e gerando receitas na Europa. Foi assim que a história da canade-açúcar começou como opção para a ocupação do Brasil, inaugurando nova forma de colonização. Com terras em abundância o açúcar poderia ser 
produzido em larga escala. Junqueira \& Dantas (1964) relatam diversos registros da presença de plantios de cana-de-açúcar bem como da fabricação de açúcar desde a segunda década do século XVI. A cana-de-açúcar espalhouse pelo litoral paulista em 1548, experimentou seu primeiro ciclo de expansão e declínio entre meados do século XVIII de meados do século XIX, segundo Veiga Filho (2002). Desde então e até os dias atuais é considerada uma das principais fontes de matéria-prima do setor agroindustrial.

Na economia do país a produção de cana-de-açúcar tem um papel muito importante, considerando a vasta área cultivada, o grande número de fornecedores e de usinas, a forte participação no mercado de insumos, máquinas e equipamentos, a grande ocupação da mão-de-obra direta ou indireta, o consumo interno e a exportação dos produtos agro-industriais. 0 Brasil é o maior fornecedor de cana-de-açúcar do mundo, participando com $25 \%$ da produção mundial, seguido pela Índia com $24 \%$ e China com $5 \%$. Os dados da FAO mostram que o Brasil lidera no mundo tanto a produção, com 360.556.000 toneladas, como a área colhida, com 5.062.000 hectares no ano de 2002. A área de cana-de-açúcar colhida no Brasil na safra 2001 foi de 4.966.972 hectares, com uma produção de 347.506.109 toneladas. A produtividade média, em 2001, foi de $69.96 \mathrm{~kg} / \mathrm{ha}$ e em 2002 de $71.23 \mathrm{~kg} / \mathrm{ha}$, aumentando em 1,8\% (FNP Consultoria \& Agrolnforamtivos, 2003).

Aproximadamente a metade da produção brasileira é exportada. Em 2000 ingressaram para a balança comercial 1,2 bilhões de dólares norteamericanos. A agroindústria canavieira emprega em torno de um milhão de trabalhadores, principalmente para a realização do corte manual da cana, de acordo com o relatório da União da Agroindústria Canavieira de São Paulo UNICA (2002). 
O incremento na produção de cana no Estado de São Paulo, devido á expansão da cultura e o auto-abastecimento, levou a considerar ao Estado como maior fornecedor de açúcar e de álcool do Brasil (Ramos, 2001). O Estado de São Paulo é fornecedor de $60 \%$ de todo o açúcar brasileiro, e responsável por $70 \%$ das exportações nacionais. Das 307 unidades industriais cadastradas no Brasil, 128 localizam-se nesse Estado (UNICA, 2002).

O setor sucroalcooleiro é de grande importância sócio-econômica no Estado de São Paulo. A cultura da cana-de-açúcar no ano 1998 representou $66,52 \%$ da área cultivada com essa cultura no país e absorveu $38,59 \%$ da força de trabalho agrícola envolvida na cultura da cana no Brasil. Dados do IBGE (2002) apresentam a grande importância da cultura da cana-de-açúcar na geração de renda no Estado de São Paulo, representado 56,40\% do valor da produção dos produtos selecionados pela SEADE.

A cana-de-açúcar constitui-se na principal cultura cultivada no Estado de São Paulo, participando com $27,2 \%$ do valor da produção agropecuária, os 10.727 fornecedores de cana do Estado, representados pela CÂMARA PAULISTA DO SETOR SUCROALCOOLEIRO - ORPLANA, foram responsáveis pela entrega de aproximadamente $24 \%$ de toda a matéria prima processada na safra 2000/2001, ou seja, perto de 36 milhões de toneladas de cana, valoradas em cerca de 178 milhões de reais (CÂMARA PAULISTA DO SETOR SUCROALCOOLEIRO, 2002).

Gonçalves \& Souza (1998a) salientam a importância da cana para a agroindústria Paulista. Sendo a principal cultura, no triênio 1994/96 a cana representou o $27,2 \%$ do valor anual da produção do estado. Os $R \$ 2,2$ bilhões da renda bruta da cana para indústria representam mais que o dobro do valor gerado pela produção da carne bovina e mais de 4 vezes da carne de frango. Estes mesmos autores fazem referência em igual período de tempo, em relação 
da área cultivada, para as principais lavouras paulistas a cana apresentou crescimento expressivo, que foi de 2,6 milhões de ha para 2,8 milhões de ha, incorporando 212 mil ha de área cultivada. Na demanda de força de trabalho a cana para indústria contribui com 368,6 mil de EHA (Equivalentes-homens-ano) de um total de $810,5 \mathrm{EHA}$, e representa o 45,5\% do emprego agropecuário paulista. A produção de cana para indústria é a maior empregadora de trabalhadores não qualificados, principalmente na colheita.

Os 38.815 fornecedores de cana independentes no Brasil participaram com $27,25 \%$ da produção de cana total entregue na safra brasileira de 1998/99, que foi no total ao redor de 285 milhões de toneladas. No estado de São Paulo, esse percentual não é muito diferente. Os 11.570 fornecedores do estado participaram apenas com $26 \%$ de toda a matéria-prima da referida safra paulista. No que se refere ao tamanho individual dos fornecedores, no Estado de São Paulo, aproximadamente $77,5 \%$ são pequenos, com produção de até 4.000 toneladas por ano, sendo responsáveis por $21 \%$ da cana entregue por fornecedores. Os fornecedores médios, com produção entre 4.000 e 10.000 t de cana, representam $13,1 \%$ do total e participam com $18 \%$ da cana entregue. Os restantes $61 \%$ da produção foram realizados por $9 \%$ dos fornecedores, que entregaram mais de 10.000 toneladas de cana (Moraes, 1999).

Quanto ao aspecto social, destaca-se em Serodio (1999) a questão dos empregos como sendo um fator importante a ser considerado, posto que são gerados um milhão de empregos diretos na agroindústria canavieira no Brasil, sendo 511 mil na produção de cana-de-açúcar e os demais distribuídos nas diversas atividades da agroindústria de açúcar e de álcool. No Estado de São Paulo são 600.000 postos de trabalho diretamente ligados ao setor, sendo que o piso salarial dos trabalhadores do setor é $70 \%$ maior que o salário mínimo segundo dados da UNICA $(1999,2002)$. Porém, deve ser lembrado que uma parte significativa destes empregos está ameaçada, já que a proibição de 
queimadas como método de despalha impõe o uso de colhedeiras mecânicas, com a conseqüente redução da mão-de-obra empregada (Moraes, 1999).

As principais usinas paulistas estão localizadas na região de Ribeirão Preto e de Piracicaba, as quais apresentaram os maiores porcentuais de áreas de cana pertencentes aos fornecedores. A região de Piracicaba produz aproximadamente $18 \%$ da cana do estado de São Paulo (CÂMARA PAULISTA DO SETOR SUCROALCOOLEIRO, 2002). A área média de produção por fornecedor de cana neste Estado é de 52 ha. Na Associação de Sertãozinho, que é a maior associada da CÂMARA PAULISTA DO SETOR SUCROALCOOLEIRO em termos de produção, a área média de produção de cana é de 87 ha (UDOP, 2001). Isso significa que a área média de produção de cana na região de Piracicaba é bem inferior à média do estado de São Paulo. Essa tendência é demonstrada por Ramos (1999) cujos dados apontam a área média cortada pelos fornecedores de Piracicaba como sendo de 22,8 ha.

$\mathrm{Na}$ região de Piracicaba $58,8 \%$ das unidades de produção agropecuárias se dedicam a culturas semiperenes, com $44,8 \%$ da área regional, ou seja, 164,1 mil hectares, cultivada com esse tipo de ocupação, sendo a cana-de-açúcar a principal delas (Gonçalves \& Souza, 1998b).

Os fornecedores de cana do estado de São Paulo encontram-se organizados através de 19 associações de classe, agregados na CÂMARA PAULISTA DO SETOR SUCROALCOOLEIRO, sendo que a de Piracicaba é a que possui maior número de fornecedores, somando 3.826 , o que significa $31 \%$ do total dos fornecedores do estado, com uma área média de 28 ha por fornecedor e a segunda maior produção de cana. A Associação de Fornecedores de Cana de Piracicaba (AFOCAPI) contou com fornecedores de cana-de-açúcar distribuídos em 17 unidades industriais, em 58 municípios do estado de São Paulo. O histórico das safras 1984/1985 até 2001/2002, mostra que a produção dos fornecedores da AFOCAPI oscilou entre 6,8 e 7,9 milhões 
de toneladas, atingindo dois valores extremos fora dessa faixa, de 8,6 milhões de toneladas na safra 1998/1999 e de 5,4 milhões de toneladas na safra 2000/2001. Essa produção representou um percentual de participação na produção dos fornecedores da ORPLANA de 25\% no período 1984 até 1991, caindo para uma faixa entre $22 \%$ e $20 \%$ no período 1992 até 1995 , e sofrendo redução sistemática, de aproximadamente um ponto percentual ao ano, de 1996 até a safra 2000/2001, quando a participação foi de 15\%. Vale ressaltar que essa queda no percentual de participação não adveio de uma redução da produção da região de Piracicaba, mas sim de um aumento da produção do estado (CÂMARA PAULISTA DO SETOR SUCROALCOOLEIRO, 2004).

No município de Piracicaba a superfície com cana-de-açúcar, em 1991, era de 86.819 hectares, ocupando 49,3\% da área do município (Sparovek \& Lepsch, 1995). Avaliações realizadas nessa região determinaram que pelo menos $37 \%$ da área atualmente cultivada com a cultura estaria sujeira a uma mudança de uso por serem de terras inaptas à colheita mecanizada (Sparovek et. al., 1997), adaptação essa do sistema de produção necessária devido à proibição da queima como técnica de despalha prévia à colheita manual. Isto porque a viabilidade da mecanização é limitada pela declividade das terras, sendo $12 \%$ o limite acima do qual a mecanização é bastante dificultada. Essas terras envolvem solos com alta suscetibilidade à erosão e degradação, e estão predominantemente em áreas de pequenos fornecedores. Esse cenário não se alterou, desde então (Pinto, 2002).

\subsection{Como a legislação atual afeta os fornecedores de cana}

Em 1941 foi promulgado o Estatuto da Lavoura Canavieira pelo Decreto - Lei No. 3855, de 21 de Novembro de 1941, que disciplinou rigidamente as relações entre fornecedores de cana e fornecedores de açúcar e 
álcool. Foi considerado fornecedor todo lavrador que, cultivando terras próprias ou alheias, tivesse fornecido canas a uma mesma usina, diretamente ou por interposta pessoa, durante três ou mais safras consecutivas (Moraes, 1999).

A partir de maio de 1998 o setor sucroalcooleiro passa por desregulamentação oficial, afastando-se o governo federal de diversas etapas da produção, principalmente aquelas concernentes à comercialização da canade-açúcar, do açúcar e do álcool. (Moraes, 1999). Como conseqüência, ocorreu a liberação dos preços, antes estabelecidos pelo governo, que num primeiro momento, resultou em redução dos valores pagos pela cana aos fornecedores (Banco do Brasil, 2000). As associações de classe, agregadas na ORPLANA e ÚNICA, passaram a ter um papel importante nas negociações, que resultaram na criação de um Conselho dos Fornecedores de Cana, Açúcar e Álcool do Estado de São Paulo - CONSECANA-SP, que passou a estabelecer a sistemática de pagamento e de contrato de venda e compra de cana-de-açúcar, reconduzindo os preços a uma certa estabilidade (CÂMARA PAULISTA DO SETOR SUCROALCOOLEIRO, 2004).

Na mesma ocasião, a legislação de cunho ambiental, criava restrições cada vez maiores para a atividade canavieira. A legislação atual exige adequações no sistema de produção da cana-de-açúcar e restringe, gradativamente, a queima como método de despalha antes do corte, com o que a colheita deve ser da cana crua, seja com corte manual ou mecanizado. Algumas áreas poderiam tornar-se improdutivas pela impossibilidade da adequação ao sistema mecanizado, ou pela inviabilidade econômica da cana crua colhida manualmente.

Em 1988, o decreto $\mathrm{n}^{\circ} 28.848$ de 30 de agosto de 1.988 proibiu a queimada da cana em áreas consideradas de preservação ambiental, próximas a redes elétricas, rodovias e ferrovias e próximas ao perímetro urbano. Embora 
não fosse dirigida especificamente ao setor canavieiro, este teve de adequar-se aos dispositivos da lei no sentido de:

a) obter licença dos órgãos governamentais, através do pedido formal, para as áreas onde era praticada a queimada;

b) respeitar os horários preestabelecidos para a queima;

c) dispor de uma equipe de plantão na hora da queimada para emergências em caso de propagação do fogo, inclusive com carros pipa de combate a incêndios;

d) restringir rigorosamente a queima nas áreas limitadas pelo decreto.

O decreto $\mathrm{n}^{\circ} 42.056$ de 06 de agosto de 1997, publicado no Diário Oficial do Estado de São Paulo, inaugura a legislação ambiental específica para o setor, uma vez que normaliza a queima da cana-de-açúcar. O decreto afirma que a queima da cana, como método auxiliar a colheita, fica proibida no estado de São Paulo, e será admitida apenas em caráter excepcional e transitório. Estabelece um cronograma, ao fim do qual essa prática deverá estar erradicada nos canaviais. Assim, nas áreas em que a colheita é hoje mecanizável, a redução da área com queima da cana seria efetuada ao ritmo de $25 \%$ a cada dois anos, sendo que no mínimo $10 \%$ de eliminação já ocorresse no primeiro ano. Dessa forma, ao final de oito anos, a queima em áreas mecanizáveis deverá estar completamente eliminada. Nas áreas em que a colheita não é mecanizável, o ritmo de redução da área de cana queimada seria de 13,35\% a cada dois anos de maneira que, ao fim de quinze anos, a queima da cana esteja eliminada nessas áreas. As áreas mecanizáveis correspondiam, na ocasião, a 60\% da atual área cultivada com cana no Estado de São Paulo. O acompanhamento desse cronograma seria feito pela CATI, que na Portaria 19 de 23/12/97 estabelece um Plano de Eliminação de Queimadas (PEQ) e pela CETESB, que pune as infrações ambientais com multas. 
Em 03 de Maio de 2000 foi publicada, a Lei Estadual número 10.547, que normaliza o emprego do fogo me práticas agrícolas, pastoris e florestais no Estado de São Paulo. A Lei estabelece regras de execução e medidas de precaução a serem obedecidas e as distâncias a serem observadas de 15 até $100 \mathrm{~m}$ das faixas de segurança de linhas de transmissão de energia elétrica, subestações, e estações de telecomunicação e de rodovias e ferrovias, e de 50 m a partir de aceiro ao longo redor de Unidades de Conservação Ambiental. Estabelece também que o emprego do fogo depende de autorização prévia junto à Secretaria do Estado do Meio Ambiente. Trata também da redução gradativa do emprego de fogo como método despalhador para o corte de canade-açúcar, em áreas possíveis de mecanização da colheita, não podendo a redução ser inferior a um quarto da área mecanizável de cada unidade agroindustrial, a cada período de cinco anos. As lavouras de até 150 ha não ficaram sujeitas à redução gradativa do emprego do fogo, o que foi um atenuante para os pequenos fornecedores. A regulamentação posterior dada pelo decreto número 45.870, de 22 de Junho de 2001, estabelece que a redução gradativa deverá ocorrer considerando-se a área integral e não somente aquela possível de mecanização da colheita.

A Lei número 11.241, de 19 de setembro de 2002, posteriormente regulamentada pelo Decreto número 47.700 , de 11 de março de 2003, dispõe especificamente sobre a eliminação do uso do fogo como método despalhador e facilitador do corte de cana-de-açúcar. Ambas estabelecem que em áreas que permitem a colheita mecanizável, a queima deverá ser eliminada em $20 \%$ da área cortada a partir de 2002, sendo eliminada completamente em 2021. Já para áreas com declividade superior a 12\% ou menores que 150 ha a queima deverá ser eliminada em $10 \%$ da área cortada a partir de 2011, sendo eliminada completamente em 2031. Nesses dois instrumentos legais, também são estabelecidos os mecanismos de requerimento e comunicação prévia de queima controlada da cana-de-açúcar para as áreas onde ainda é permitido a 
queima. A resolução SMA - 15, de 13 de março de 2003, aprova as instruções detalhadas para esses procedimentos de requerimento e comunicação prévia. Dessa forma, o cenário futuro aponta para a necessidade de encontrar-se alternativas ao uso da queima como facilitador do corte.

A questão ambiental afeta a todos e neste sentido cresce a tomada de consciência de que muitos dos problemas dos instrumentos de gestão ambiental empregados decorrem de um conhecimento insuficiente das condições e modalidades de produção existentes, bem como da conseqüente inadequação das alternativas propostas aos agricultores. As respostas aos problemas devem estar em sintonia com o contexto social, econômico e agroecológico local e adequados às diferentes categorias e atores sociais presentes (Neumann \& Loch, 2002).

$\mathrm{Na}$ atual circunstância, apenas a expansão para novas áreas poderia suprir a demanda de produto da agroindústria canavieira. Com isso a área plantada com cana no Estado de São Paulo poderia até reduzir-se. Entretanto, necessariamente haveria mudanças na distribuição espacial desse plantio com o abandono de áreas declivosas e incorporação de áreas planas. Outra solução seria desenvolver-se equipamentos que possibilitassem a colheita em áreas com declive mais acentuado que 12\% (Gonçalves \& Souza, 1998b), ou provocar modificações no sistema de produção que assim permitissem a colheita mecanizada em áreas declivosas.

Adicionalmente, às restrições para uso da queima como método de despalha e às obrigações de manter e recompor as áreas de conservação e proteção ambiental, a nova legislação trouxe mais uma potencial dificuldade para os fornecedores de cana-de-açúcar a partir da entrada em vigor da Lei número 9.456, de 25 de abril de 1997, regulamentada pelo Decreto número 2366, de 05 de novembro de 1997, conjunto de regras conhecido como "lei de 
proteção de cultivares". Isso porque, a partir de então, os plantadores de canade-açúcar devem adquirir os direitos para a utilização das variedades registradas pelas instituições, públicas ou particulares, que trabalham com o melhoramento genético dessa espécie.

O conjunto dessas novas regras que surgiram concomitantemente, expressas pela legislação apresentada acima, apesar de emanadas democraticamente da sociedade visando, regra geral, o bem comum e emanadas de origens diferentes, num primeiro instante representaram um incremento no custo de produção da cana-de-açúcar e um sentimento entre os fornecedores da existência de pressão da sociedade contra sua atividade econômica principal.

\subsection{Mudanças no sistema de produção da cana-de-açúcar}

Tecnologicamente, a produção da cana-de-açúcar acompanha os avanços do setor agrícola. Entretanto, devemos lembrar da existência de fornecedores em processo de adoção ou potencialmente aptos a inovar e que ainda não o fizeram em conseqüência de diversos fatores (Veiga \& Souza, 1995). Existe a necessidade de reconhecer e intervir nos processos produtivos, objetivando que o fornecedor atinja níveis de eficiência mais competitivos. Tal estratégia passa, obrigatoriamente, por uma análise do perfil tecnológico da produção, das formas de organização, das políticas públicas, entre outras, que permitam alterar em profundidade o padrão produtivo. Para realizar uma intervenção em sistemas de produção de cana-de-açúcar, é indispensável à análise dos componentes principais na determinação de nível tecnológico e caracterização dos fornecedores. Práticas tecnológicas são todas as ações dos fornecedores no processo de produção no que diz respeito ao manejo e ao 
gerenciamento da propriedade, procurando destacar as vantagens e as necessidades de sua realização (Alexio \& Souza, 2001).

No que se refere às mudanças tecnológicas Basaldi (1994) comenta que os trabalhos científicos desenvolvidos em parceria por usinas de açúcar e álcool, indústrias fornecedoras de máquinas agrícolas, universidades e institutos de pesquisa têm demonstrado vários aspectos positivos, do ponto de vista técnico, na adoção da colheita mecânica da cana crua, apontando para uma rápida mecanização dessa fase do cultivo, por parte das usinas, no estado de São Paulo. As modernas tecnologias geradas e incorporadas às culturas, visando baixar os custos de produção e melhorar a qualidade do produto em função da competitividade entre os mercados agrícolas, caracterizados pelo grande aumento na produtividade do trabalho, principalmente com a mecanização das várias fases do cultivo e uso de herbicidas nos tratos culturais, têm apresentado, como conseqüência, economia de mão-de-obra e alijamento de um grande número de trabalhadores rurais dos processos produtivos. Por isso, conhecer profundamente os desdobramentos da adoção de modernas tecnologias nesta cultura e os reflexos socioeconômicos nas principais regiões fornecedoras é fundamental para subsidiar não só a ação estatal, nos seus diversos níveis, como também das organizações dos trabalhadores rurais.

Para Eid (1996), o progresso técnico na agricultura canavieira abrange as quatro fases do processo de produção, que são o preparo do solo, o plantio, os tratos culturais e a colheita, através de inovações mecânicas, físico-químicas e biológicas. A modernização dessas fases implicam quase sempre na mecanização ou automação de alguma etapa com a conseqüência da diminuição do emprego de mão-de-obra. 
A queima da cana-de-açúcar como método de despalha é uma atividade secular, utilizada também em outros países fornecedores de açúcar, em variadas proporções. No México, África do Sul e Havaí queima-se $100 \%$ da área de cana-de-açúcar; na Colômbia, 95\%; Argentina, 90\%; Austrália, 40\% e Cuba, 5\% (Silva, 1997). Embora a questão das queimadas da cana-de-açúcar já venham sendo discutida há bastante tempo no estado de São Paulo, foram as novas leis que passaram a causar um impacto maior no setor, provocando necessidades de mudança. Gonçalves \& Souza (1998b) ressaltam o dinamismo setorial com incrementos progressivos de tecnologia elevando a produtividades da lavoura canavieira e superando obstáculos à sua expansão. Dessa forma, o complexo sucroalcooleiro mostra-se intensamente dinâmico na incorporação do progresso técnico, o que significa economia de fatores, naturais ou humanos. A cada conquista tecnológica a lavoura da cana supera progressivamente entraves econômicos e ambientais.

Uma questão que está causando fortes impactos ao setor, tanto no que se refere aos investimentos necessários para a mecanização, como no desemprego decorrente, é a proibição das queimadas da cana-de-açúcar como método de despalha. Para permitir a continuidade da atividade canavieira nas áreas com restrições à colheita mecanizada, procuram-se alternativas de produção adaptáveis à realidade do fornecedor. O corte manual da cana crua, com a palha, é inviabilizado pelo seu alto custo de produção, em média $45 \%$ maior que o da cana queimada, e pelo Acordo Seletivo do Trabalho, que prevê a queima da cana para o corte, dadas as dificuldades que o operário encontra para colher cana crua. Desta forma, a solução mais econômica para se colher a cana crua é através da colheita mecanizada. Porém, as dificuldades encontradas pelos fornecedores de cana quanto ao cumprimento do plano de Eliminação de Queimadas advêm da falta de recursos para adquirir as colhedeiras mecanizadas associada dificuldade para obtenção de financiamento, além das condições topográficas de algumas regiões, que 
impossibilitam a colheita mecanizada. Assim, são necessárias alternativas de produção para os pequenos fornecedores que não tenham capacidade de mecanizar-se, ou para aquelas áreas cujas condições topográficas impeçam a mecanização (Moraes, 1999).

A mecanização da colheita da cana pode ser dividida em três etapas: a colheita, o carregamento e o transporte até a usina. No Brasil, o transporte da cana foi a primeira etapa a ser mecanizada, com a introdução, por volta de princípios dos anos 50, dos caminhões em substituição aos animais de tração. Posteriormente, nos anos 60, o carregamento da cana colhida para os caminhões deixou de ser manual e passou a ser realizado por carregadoras mecânicas. Essas duas etapas mecanizadas foram adotadas em praticamente toda a área colhida de cana-de-açúcar. Mais tarde, a etapa do corte, muitas vezes combinada com o carregamento, passou a ser estudada, apesar de ser esporadicamente adotada nos anos 70 e 80 . A colheita mecanizada exige modificações técnicas e logísticas que afetam desde o plantio até o recebimento da cana na usina. A primeira tarefa é redimensionar o comprimento dos talhões de cana, a fim de evitar perda de tempo com manobras; em seguida, é necessário nivelar os terrenos que possuem declividade elevada. Depois, é preciso limpar com bastante eficiência o terreno sobre o qual as colhedoras irão operar, para evitar que tocos, árvores e buracos venham a danificar a máquina. Por fim, é necessário rever o espaçamento adequado entre as fileiras de cana, de maneira a garantir que as máquinas trafeguem com as rodas entre as linhas de cana e não danifiquem as soqueiras. Todas essas mudanças no sistema produtivo, mais a aquisição ou aluguel das máquinas e equipamentos, exigem vultuosos recursos financeiros, nem sempre acessíveis aos pequenos fornecedores (Guedes \& Ré, 1999). Por essa razão, a mecanização da colheita atingia somente $25 \%$ da área plantada no ano de 2002 (UNICA, 2002). 
De acordo com Veiga et al. (1994) na mecanização do corte influem uma série de componentes que podem individualmente pesar mais para uma determinada unidade de produção que para outras, dependendo das condições de capitalização, nível tecnológico, capacidade gerencial e operacional, acesso ao mercado de insumos entre outros fatores. Esta problemática ocasionada pela legislação, como Gonçalves \& Souza (1998b) comentam, gera situações que afetam os empregados e fornecedores que irão encontrar grandes dificuldades para se ajustarem. Os fornecedores de cana com as áreas liberadas por inaptidão devem enfrentar o desafio de buscar outras culturas para os plantios em declive, a espera de políticas públicas adequadas.

A proibição da despalha por queima levará à depreciação patrimonial das glebas declivosas, com isto estimula-se a eliminação dos pequenos e médios fornecedores, 90\% deles com área inferior a 125 hectares, que deverão procurar outra atividade para sobreviverem (Gonçalves \& Souza, 1998b). Fazse necessário, portanto, maior atenção e determinação de alternativas para os que estão e serão excluídos deste processo produtivo (Romanach \& Caron, 1999).

Segundo Bernardes \& Sparovek (1998) há insuficiência de informações sobre sistemas de produção compatível com as áreas inaptas à produção de cana-de-açúcar sem queima. Assim, as culturas perenes seriam as mais apropriadas para os sistemas de produção alternativos, devido às características de adaptação ao relevo e conservação do solo, que poderiam ser conduzidas em associação a culturas anuais e semiperenes, compondo assim sistemas agroflorestais que seriam mais apropriados para a ocupação dessas terras declivosas. 


\subsection{Sistemas Agroflorestais (SAFs) como alternativa}

SAFs são sistemas de uso da terra onde espécies lenhosas perenes são introduzidas ou retidas na mesma unidade de manejo de solo com culturas agrícolas ou com animais em arranjo espacial ou seqüência temporal, ocasionando algum tipo de benefício (Nair, 1989). Já a definição utilizada pelo International Centre for Research in Agroforestry (ICRAF, 2002) e feita por Lundgren e Raintree em 1982, estabelece que SAF é um conjunto de tecnologias e sistemas de uso da terra onde espécies lenhosas perenes como árvores, arbustos, palmeiras, bambus, etc., são utilizados deliberadamente numa mesma área em conjunto com cultivos agrícolas e animais, dentro de um arranjo espacial ou uma seqüência temporal, existindo interações ecológicas e econômicas entre os diferentes componentes (Sinclair, 1999).

Com a proposta de melhorar o manejo do uso da terra para obter benefícios ambientais e econômicos, seria necessário promover melhores sistemas com pesquisa e desenvolvimento participativos; melhorando a sustentabilidade ambiental e econômica com o uso de Sistemas Agroflorestais (ICRAF, 2002). Inicialmente a introdução deve ser compatível no contexto das atividades produtivas atuais, sem imposição de mudanças radicais que são socialmente e economicamente inviáveis.

Fator de êxito apresentado por Dubois (1998) para a adoção de sistemas agroflorestais é que estes devem ser planejados de maneira participativa, ou seja, com pleno envolvimento dos agricultores. Assim, a geração e difusão tecnológica devem ser iniciadas através da construção de uma base de referência sólida que contemple os interesses de técnicos e agricultores. As espécies devem ser escolhidas tomando em conta sua adequação às características locais de clima, solo e topografia, o valor atual ou prospectivo de seus produtos no mercado, apresentar crescimento rápido, não 
ser sujeitas a doenças ou pragas de controle difícil no possível, apresentar perspectivas boas de beneficiamento ou pre-beneficiamento agregando renda adicional para o fornecedor.

O uso de Sistemas Agroflorestais como estratégia para a recuperação de matas ciliares não é permitido pelos órgãos ambientais, em função da ausência de informações sobre as vantagens e desvantagens para esse uso específico. É necessário avaliar o contexto social, econômico e ambiental em que se situa a área a ser preservada. Foi demonstrado que o uso de SAFs simples em áreas de recuperação florestal puderam reduzir o custo de manutenção em $16 \%$ e que não influenciaram negativamente os atributos biológicos do solo nem prejudicaram o crescimento das árvores nativas destinadas à recuperação de mata ciliar (Vaz da Silva, 2002).

Bernardes et al. (1998) concluíram que os sistemas agroflorestais apresentam potencial para manter a atividade agrícola na região de Piracicaba, ocupando espaços principalmente em áreas com dificuldade para a colheita mecanizada da cana-de-açúcar no modelo tecnológico atual, dando maior sustentabilidade ao setor sucroalcooleiro. Esses autores, realizando estudos prévios envolvendo diversos especialistas dos setores agrícola e florestal, e utilizando-se de modelos matemáticos de previsão de crescimento e produção das culturas em monocultivo e combinadas entre si, demonstraram que um SAF envolvendo a cultura da cana-de-açúcar em faixas de $60 \mathrm{~m}$ de largura, intercalada com seringueiras em aléias duplas e palmiteiros ocupando as faixas entre as seringueiras, podiam ser mais rentáveis que a cultura solteira da canade-açúcar no mesma local. Adicionalmente, verificaram que a erosão prevista no SAF sem terraceamento na faixa de cana era inferior àquela na área com monocultivo de cana-de-açúcar. A retirada do terraceamento na faixa da canade-açúcar permite que a colheita mecanizada seja realizada em declividades superiores aos $12 \%$ tidos como limite máximo para áreas com terraços. Em 
estudo posterior, Pinto et al. (2002) postulou que os SAFs podem compatibilizar a produção de cana-de-açúcar, conservação de recursos naturais e colheita mecanizada em significativa área da região de Piracicaba, havendo diversas espécies arbóreas para compor neste sistema.

Haishui \& Kejun (1998) descreveram a utilização de cana-de-açúcar em SAF com seringueira no Sul da China. A cana-de-açúcar foi plantada no espaçamento de $0.3 \times 0.8 \mathrm{~m}$ entre as fileiras de árvores de seringueira em espaçamento normal. A colheita da cana-de-açúcar foi feita por três ou quatro anos. Os autores atestam que existiam 844 ha de cana-de-açúcar nesse tipo de SAF na região e que a sua produtividade variava de 23 a 30t/ha e que a intercalação resultava em aumento do crescimento da seringueira.

Pinto (2002) demonstrou que o Índice de Equivalência de Área (IEA), que é a razão entre a área dos monocultivos dos componentes de um SAF sobre a área do SAF que resulte numa mesma produção daqueles, era similar entre o monocultivo de cana-de-açúcar e os SAFs de cana-de-açúcar com eucalipto ou com seringueira. O autor então concluiu que os SAFS com canade-açúcar podem ser implantados de maneira geral no município de Piracicaba, especialmente me solos com alta suscetibilidade à erosão presentes no intervalo de declividade entre $12 \%$ e $20 \%$. A cana-de-açúcar deve ser cultivada, nesses SAFs, em aléias em contorno nas terras declivosas, com sistema mecanizado de colheita.

Os entraves para a adoção de Sistemas Agroflorestais podem ser ecológicos, econômicos ou sociais, os quais podem ser identificados corretamente com ajuda dos fornecedores facilitando a comparação das alternativas de produção e motivando a aceitação das novas tecnologias agroflorestais (MacDicken \& Vergara, 1990). De grande importância é a pesquisa participativa, concebida e realizada em conjunto com fornecedores 
para a análise de sistemas a eles endereçados. A inclusão de agricultores na pesquisa incorpora uma gama de conhecimentos informais e aumenta a abrangência dos estudos, permitindo trocas e evoluções de ambas as partes. A criação de projetos pilotos que envolvam a pesquisa-ação de SAFs, junto a agricultores pode ser uma maneira de ampliar a escala de atuação e a capacidade de geração e circulação de conhecimentos (Vaz da Silva, 2002), favorecendo a adoção de inovações pelos fornecedores.

\subsection{Entraves para a adoção de SAFs}

Adoção de tecnologia corresponde ao estágio final de um processo efetivo de assimilação e emprego de informações e técnicas, que se inicia na descoberta até a aplicação de uma idéia num determinado processo de produção (Martin, 1992). Para a adoção de sistemas agroflorestais pelos fornecedores de cana-de-açúcar, primeiramente esses deverão ter um conhecimento adequado da nova tecnologia proposta. Também, alguns conceitos básicos relacionados com a mudança tecnológica devem ser considerados.

Peach (1955) define tecnologia como sendo "o conhecimento de como usar os recursos" e recursos como "os materiais naturais ou criados e os humanos a partir dos quais os bens e serviços são produzidos". Para que os recursos sejam utilizados para a produção, devem ser organizados e combinados. Uma determinada combinação de recursos e seus respectivos produtos é chamada de uma função de produção. Os recursos usados com fins produtivos são geralmente chamados de fatores de produção e incluem terra, mão-de-obra, capital e tecnologia.

Já Ruttan (1960) define mudança tecnológica como "uma mudança nos parâmetros de uma função de produção, os quais resultam diretamente do 
uso do conhecimento. Aplica-se às mudanças nos coeficientes de uma função que relaciona os insumos aos produtos, mudanças estas que resultam da introdução prática das inovações na tecnologia e na organização econômica".

Heady (1949) afirma que o progresso tecnológico na empresa individual tem duas propriedades gerais: o desenvolvimento de uma nova função de produção de maneira que um aumento na produção seja decorrência de uma determinada aplicação de recursos ou insumos; e o progresso tecnológico deve imediatamente aumentar os lucros ou diminuir os prejuízos da firma. Como regra quase geral o custo deve diminuir. Isto quer dizer que, pelo progresso tecnológico, ou a produção é aumentada usando-se os mesmos recursos, ou então a mesma produção é obtida utilizando-se menor quantidade de recursos usuais. Para esse autor, a mudança tecnológica é expressa como quantidade de produção por unidade de insumo total entre dois períodos.

Para Szmrecsányi (1979) o planejamento agropecuário tende a ser predominantemente de caráter indicativo, baseado na identificação e adoção de medidas institucionais de incentivo, organização e assistência para assegurar a mobilização e cooperação dos fornecedores. O mercado dos novos produtos agropecuários, e a instrução dos agricultores em modernas técnicas de produção.

Os critérios que guiam a pesquisa na busca de prioridades e na especificação de alguns aspectos das novas tecnologias que devem estar presentes, segundo Chapman (1984), a fim de propiciar os mais altos níveis de retorno e de aceitabilidade são a utilização dos recursos, a contribuição aos objetivos da família, os requerimentos institucionais, gerenciais, e agroclimáticos, além da aceitabilidade pelos agricultores. 
A adoção de modernas tecnologias agrícolas pelo fornecedor rural, como explica Rolim (1989), é sempre dependente de uma série de fatores, intrínsecos ou extrínsecos à própria tecnologia e ao ser humano que com ela está se relacionando, sendo que determinadas tecnologias têm maior facilidade de adoção pelo fornecedor do que outras. Alguns fatores que influenciam a adoção de uma tecnologia são os preços dos produtos e dos insumos e materiais utilizados, posse da terra, produção total de cana-de-açúcar, acesso ao crédito rural, além da existência de política de incentivo à produção. Os fatores importantes no processo de difusão de inovações tecnológicas são a organização da unidade produtiva, a especialização, o tipo de mão-de-obra utilizada e a disponibilidade de assistência técnica aos fornecedores.

Caron (1986) comenta que os fornecedores podem ser diferenciados em Familiares, Capitalistas, Rentistas e Espúrio, demonstrando a heterogeneidade existente na categoria de fornecedores de cana-de-açúcar.

Rogers \& Havens (1961), conceituam difusão como sendo o processo pelo qual uma inovação é comunicada, através de certos canais, ao longo do tempo, entre os membros de um sistema social. Referindo-se ao processo de tomada de decisão para inovar, consideram como um processo mental, através do qual o indivíduo vai desde o primeiro contato com a inovação até a decisão para continuar o seu uso integral. É diferente, portanto, do processo de difusão e implica no processo de adoção individual, pois é do resultado deste processo entre os diferentes membros de um sistema social que a difusão se dá. Adoção é, por conseguinte, um processo de decisão individual, ao passo que difusão é um processo social.

Segundo Petersen (1997), citado não basta encontrarmos uma proposta técnica eficiente, devemos procurar o envolvimento dos agricultores na geração deste conhecimento que pode aproximar-se à realidade local, e 
proporcionar melhores resultados em termos de adoção de tecnologia. Existem indivíduos que adotam uma dada inovação mais rapidamente do que outros; possuem, em outras palavras, uma maior capacidade de inovação. O autor classificou os adotantes em termos de sua "capacidade de inovação", isto é, em função do tempo relativo que o indivíduo leva para adotar em relação aos demais membros de seu grupo. Considerando a difusão como um processo em que os adotantes se distribuem num contínuo, mais ou menos extenso com crescente capacidade de adoção, esse autor apresentou a suposição básica de que essa distribuição assemelha-se a uma curva em formato de sino aproximando-se da normalidade.

Os fatores que favorecem a adoção de SAFs apresentados no trabalho de Current et al. (1996) são a escassez, a existência de mercados locais, a disposição a investir na recuperação do solo, produção de renda, preferência de sistemas menos intensivos, significativa participação das mulheres na produção, manejo e limitada capacidade de mobilizar recursos, limitada superfície de terra, mão-de-obra e capital. As vantagens que os fornecedores salientam são a produção de alimentos em intercultivos com árvores e a redução dos riscos advinda do consórcio das culturas com as árvores.

Para Frenzel (1999) mais informação é necessária para conhecer melhor os fatores que afetam a adoção de novas práticas, no que se refere às políticas governamentais e institucionais, com a utilização de diagnósticos participativos que levem à identificação das reais expectativas dos fornecedores. Com esses dados podem ser instaladas pesquisas com características específicas para os diferentes fornecedores, para os quais estariam gerando-se alternativas adequadas. 
Segundo Pinto et al (2001), a adoção de Sistemas Agroflorestais nas regiões canavieiras depende da simplicidade na instalação em sistemas flexíveis e no manejo para os fornecedores. A identificação de fornecedores inovadores e destacados seria o primeiro passo no processo de pesquisa e difusão agroflorestal no setor canavieiro de estado de São Paulo.

\subsection{0 método de entrevista com produtores}

Para compreender o comportamento dos agricultores é necessário ter em conta a informação existente em relação aos recursos disponíveis e às limitações a que estes são submetidos. Para a elaboração dos questionários para as entrevistas aos produtores é indispensável descrever os sistemas de produção utilizados. Os objetivos dessas entrevistas são a descrição da realidade do produtor, para compreender como e por que são realizadas certas ações e para buscar a otimização do uso dos recursos (Rodriguez Ocaña et al. 1998).

As vantagens da metodologia de entrevistas são a grande eficiência para a introdução de novas técnicas e conhecimentos, o intercâmbio de idéias e a obtenção de cooperação para demonstrações. Porém, é primeiramente uma fonte de informação primária para conhecer os problemas, as atividades e as opiniões dos produtores (Frias Morán et al., 1966). 


\section{MATERIAL E MÉTODOS}

Para compreender melhor o perfil tecnológico dos fornecedores de cana-de-açúcar, e as razões pelas quais eles adotariam ou não SAFs nas propriedades com cana-de-açúcar, optou-se pelos seguintes procedimentos.

Em primeiro lugar, em reuniões com o orientador e o diretor técnico da Associação de Fornecedores de Cana de Piracicaba (AFOCAPI) e seus técnicos de campo, foi definido o perfil mais adequado de fornecedores de cana-de-açúcar a serem entrevistados, considerando principalmente aqueles: i) das regiões canavieiras cujos solos apresentassem alta declividade, ii) que trabalhassem em área própria e iii) tivessem a atividade canavieira como principal. Essa estratificação e seleção deveu-se ao fato de ser esse tipo de fornecedor que mais sofreria restrições à sua atividade agrícola impostos pela legislação e aquele que buscaria na própria atividade agrícola a solução para as restrições. Operacionalmente, os fornecedores foram selecionados para entrevista com base nos critérios descritos e dentre aqueles cadastrados na AFOCAPI.

Consultando a mesma equipe descrita acima foi estruturado um questionário baseado naqueles de Caron (1986) e Darolt (2000), incluindo indicadores relacionados com a adoção de Sistemas Agroflorestais. No questionário aplicado aos fornecedores incluíram-se temas referentes ao sistema de produção da cana-de-açúcar, a sistema de uso da terra, à existência 
de outras atividades, ao nível de conhecimento da legislação ambiental, às alternativas de produção para áreas não mecanizáveis, aos entraves para a adoção de Sistema Agroflorestal e ao complexo agroindustrial da cana-deaçúcar.

Através de visitas às unidades fornecedoras da região de Piracicaba foram realizadas entrevistas com os fornecedores de cana-de-açúcar. No total foram entrevistados 25 fornecedores, divididos em 4 sub-regiões, sendo 7 em Rio das Pedras, 10 em Charqueada, 6 em Iracemápolis e 2 em Ipeúna, nos meses de abril e maio de 2002. Esse número representa uma amostragem de aproximadamente $10 \%$ do universo de fornecedores que atendiam aos critérios de seleção, em cada sub-região.

As entrevistas foram planejadas de acordo com as atividades dos técnicos da AFOCAPI, iniciando as viajens desde Piracicaba até as diferentes regiões, sempre com o acompanhamento de um técnico. A visita era agendada com antecipação, e realizada com a devida autorização do fornecedor selecionado.

Cada visita à propriedade incluia uma apresentação feita pelo técnico da AFOCAPI, explicando os objetivos do trabalho. O técnico acompanhava todo o restante da entrevista e da visita. O questionário era preenchido, mantendo-se uma conversação de aproximadamente uma hora e meia com o fornecedor. Logo depois era realizado um percurso pela propriedade, observando-se principalmente as áreas mais declivosas e pontos típicos identificados na entrevista, o que possibilitava relacionar as respostas com a realidade observada. Por exemplo, nos casos em que o fornecedor alegava utilizar canade-açúcar da lavoura para preparo de aguardente em destilaria própria , foram visitadas as unidades de beneficiamento, comprovando-se a industrialização da matéria-prima na propria destilaria. Nos casos de citação de outras atividades agro-pecuárias, estas foram observadas diretamente no campo. 


\subsection{Sistema de produção da cana-de-açúcar}

Com o objeto de conhecer os aspectos tecnológicos, as técnicas agronómicas utilizadas pelos fornecedores entrevistados na produção da canade-açúcar, dentre os quais destacam-se as variedades mais difundidas, a procedência as mudas para o plantio, as operações mais utilizadas na reforma do canavial e no preparo do solo, o tipo de adubo, as adubações nos diferentes estágios da cultura, a origem dos adubos utilizados, as principais práticas de manejo da cultura, de conservação do solo, o critério mais importante na determinação da época de corte da cana, o destino da palha depois da colheita, o tipo de mão-de obra empregada na produção, os principais problemas agronômicos da produção, e os aspectos técnicos a serem resolvidos pela pesquisa em cana-de-açúcar.

\subsection{Sistema de uso da terra}

Para obter-se uma idéia do tipo de posse da terra explorada para a produção da cana-de-açúcar, da capacidade de diversificação da produção e da utilização da área disponível pelo fornecedor, incluindo a cana e outras atividades, agrícolas, pecuária e florestal. Além das características da propriedade em relação às áreas com restrições ambientais, como as nascentes, as de preservação permanente e mata ciliar. 


\subsection{Outras atividades}

A importância da cultura da cana-de-açúcar dentre as outras atividades de renda do fornecedor, oferece indicadores das perspectivas de expansão da área de produção, da continuidade do entrevistado na atividade canavieira, ou da substituição da cana com outras culturas ou atividades de renda. A intenção de investimento indica as prioridades que tem o fornecedor em relação às atividades que proporcionam renda, e nas quais possue maior confiança.

\subsection{Legislação ambiental}

O nível de conhecimento das informações relacionadas às disposições que regulamentam a atividade canavieira e afetam sua produção, no referente ao ambiente. As restrições impostas pela legislação ao aproveitamento da área total da propriedade, ocasionando mudanças no sistema de produção de canade-açúcar.

\subsection{Alternativas para áreas não mecanizáveis}

As possíeis soluções ao problema que derivou da proibição da queima da cana, propondo o Sistema Agroflorestal, principalmente em áreas declivosas onde a colheita mecânica atualmente é inviável. Conhecimento do SAF, resultados de pesquisas. 


\subsection{Entraves para a adoção de Sistema Agroflorestal}

As principais restrições para adotar o sistema de produção com a cana-de-açúcar, desde o ponto de vista do fornecedor de cana. Os aspectos tecnológicos como a assistência técnica, as informações, a experiência do fornecedor, a disponibilidade de mão-de-obra especializada, os efeitos das árvores na cultura da cana-de-açúcar. As dificuldades para a comercialização da produção do SAF, e os aspectos financeiros como a ausência de crédito agrícola específico e a necessidade de investimento inicial para o início na atividade alternativa.

Na possibilidade de adoção do SAF para a produção da cana-deaçúcar, existem algumas razões que influenciariam a decisão do fornecedor, dentre as quais podem ser mencionadas a conservação dos recursos naturais, a saúde da comunidade, do consumidor, da família e pessoal, a convição ideológica, a política atual do setor, as razões econômicas e a possibilidade de melhorar a produtividade da propriedade com o melhor aproveitamento da área total.

\subsection{Complexo agroindustrial}

Devido a que o fornecedor de cana prové de matéria-prima para a indústria sucroalcooleira, como a proibição da queima prévia ao corte modificará a disponibilidade de áreas para a produção agrícola em sistema mecanizado de colheita. Os dados dos questionários foram trasladados a planilhas do Excel, resumidos em tabelas e tabulados de acordo com a origem das respostas. As perguntas estruturadas foram agrupadas em pertentagens 
médias, e as fechadas em frequência ou número de respostas dentro da amostra. 


\section{RESULTADOS}

\subsection{Sistema de produção da cana-de-açúcar}

Em relação ao perfil tecnológico dos fornecedores de cana entrevistados, os aspectos mais relevantes a serem considerados são as variedades de cana-de-açúcar atualmente utilizadas, dentre as quais destacase a RB 72454 (88\%); a origem das mudas utilizadas para o plantio é principalmente da Usina onde o fornecedor entrega a matéria-prima (Tabela 1 e 2).

Tabela 1. Principais variedades de cana-de-açúcar plantadas de acordo com o número respostas dos fornecedores entrevistados

\begin{tabular}{ccc}
\hline Item do questionário & N. de respostas & $(\%)$ \\
\hline RB 72454 & 22 & 88 \\
SP 801842 & 14 & 56 \\
RB 835089 & 8 & 32 \\
SP 801816 & 7 & 28 \\
SP 803280 & 6 & 24 \\
RB 855536 & 5 & 20 \\
RB 785148 & 4 & 16 \\
RB 855156 & 4 & 16 \\
Outras (*) & 10 & 40 \\
\hline
\end{tabular}

Obs.: As respostas aos indicadores tem por base o número de fornecedores entrevistados (25), considerando que algumas perguntas possibilitam respostas múltiplas, os percentagens não totalizam o cem percento. $\left(^{*}\right)$ Outras variedades diferentes das principais declaradas pelos fornecedores entrevistados. 
Verifica-se na Tabela 1 que o grupo de variedades adotado e plantado pelos fornecedores entrevistados pertence às gerações recentes dos programas de melhoramento, lançadas aos fornecedores de cana-de-açúcar na segunda metade da década de 90. Isso mostra que, as inovações tecnológicas que são disponibilizadas aos fornecedores e devidamente testadas localmente, são facilmente adotadas. Esse aspecto demonstra que o comportamento conservador na adoção de tecnologia não é intrínseco aos fornecedores. Assim, desde que sejam dadas as condições necessárias para a difusão do conhecimento de forma clara, demonstrando-se suas vantagens, e colocadas à disposição as condições materiais para a adoção, a tomada de decisão pelo fornecedor ocorre como finalização desse processo.

As oito primeiras variedades mecionadas pelos entrevistados coinciden com as apresentadas nos trabalhos de censos varietais difundidos pela Copersucar (Copersucar, 2003) e pela AFOCAPI (Canavieiro Paulista, 2001), no mesmo período das entrevistas que foram realizadas na região de Piracicaba. A lista acima apresentada salienta a diversidade de materiais genéticos, que os fornecedores possuem. Um exemplo a destacar é o da variedade SP 80-1842, com características vantajosas para os fornecedores de cana-de-açúcar no que se refere ao bom comportamento na soqueira, boa brotação, resitência às principais doenças e pragas, e baixa exigência em fertilidade de solos. Por outro lado o tombamento e a alta produção de massa dificulta o seu manejo na colheita mecánica, e devido a estas características atualmente é considerada em substituição.

Dentre as variedades consideradas em expansão, quatro fornecedores entrevistados inicaram a multiplicação da variedade RB 855156, dois com a RB 855453, e também dois com a RB 855556. Alguns fornecedores manifestaram que nessas áreas ainda são plantadas as variedades que em substituição com as SP 80-1842, RB 855113, e as variedades estáveis como as 
RB 72454, RB 855536, RB 855336, SP 80-1816, SP 80-3280, RB 835486, e RB 845210.

Tabela 2. Percentual médio da origem das mudas utilizadas para novos plantíos de cana-de-açúcar de acordo com o número respostas dos fornecedores entrevistados

\begin{tabular}{lc}
\hline \multicolumn{1}{c}{ Item do questionário } & Número de respostas (\%) \\
\hline Usina & 52,38 \\
Fornecedor e da AFOCAPI & 16,07 \\
Própria e da Usina & 12,74 \\
Própria & 6,07 \\
Própria, usina e fornecedor & 4,17 \\
Usina e de outro fornecedor & 3,57 \\
Usina e AFOCAPI & 2,50 \\
Própria, usina e AFOCAPI & 2,50 \\
\hline
\end{tabular}

Fonte: Dados obtidos nas entrevistas.

A grande participação das usinas como supridoras de mudas, pode ser observada na Tabela 2, suprindo mais de metade do material de plantio dos fornecedores entrevistados indica, provavelmente, uma dependência tecnológica forte dos fornecedores e uma elevada credibilidade da unidade industrial. Entretanto, a questão financeira tem um papel também importante nessa relação, uma vez que as usinas, na verdade, financiam a aquisição da muda pelos fornecedores, que pagam esse insumo básico no final da safra após o plantio com matéria-prima (colmos industrializáveis de cana-de-açúcar). Assim, verifica-se que a adoção de uma insumo relativamente caro, que participa com aproximadamente $8 \%$ do custo de fundação da lavoura (FNP Consultoria \& Agroinformativos, 2003) é facilitado pelo existência de um mecanismo de financiamento. 
Para realizar a reforma do canavial, os fornecedores preferem a utilização da grade como maneira de eliminação da soqueira $(29,17 \%)$. Esta prática poderia ser complementada com o subsolador para recuperar o solo da compactação ocasionada pelo intenso trânsito de vehículos e maquinárias durante os cinco ou mais anos da cultura a ser reformada (Tabela 3 ).

Tabela 3. Percentual médio do método utilizado pelos fornecedores entrevistados para a reforma do canavial acordo com o número respostas

\begin{tabular}{lc}
\hline \multicolumn{1}{c}{ Item do questionário } & Número de respostas (\%) \\
\hline Grade & 29,17 \\
Grade e subsolador & 23,81 \\
Arado e grade & 18,57 \\
Arado, grade e subsolador. & 15,24 \\
Arado & 7,15 \\
Herbicida, grade e subsolador & 3,57 \\
Arado, grade, herbicida e subsolador & 2,50 \\
\hline
\end{tabular}

Fonte: Dados obtidos nas entrevistas.

A maioria dos fornecedores entrevistados utiliza a combinação de várias operações para o preparo do solo antes do novo plantio de cana-deaçúcar, com a aração, a gradagem, o nivelamento e o sulcado (20,83\%), além da correspondente análise de solo e a calagem (Apêndice 1, Tabelas 10 e 11), que são indispensáveis para a preparação do solo antes da fundação da cultura semi-perene. Segundo os dados obtidos nas entrevistas, todos os fornecedores entrevistados efetuam a análise do solo, e assim conhecendo as deficiências nutricionais e as características físicas, realizam as correções. As diferentes operações dependem também da disponibilidade de implementos na propriedade, das características do talhão (que muitas vezes não permite a manobra e o intenso trânsito de maquinarias de grande porte), da época 
oportuna (as vezes coincide com a colheita e então e baixa a disponibilidade de mão-de-obra para o plantio) e da capacidade financeira do fornecedor. (Tabela 4).

Tabela 4. Percentual médio do método utilizado pelos fornecedores entrevistados para o preparo do solo acordo com o número respostas

\begin{tabular}{lc}
\hline \multicolumn{1}{c}{ Item do questionário } & $\begin{array}{c}\text { Número de } \\
\text { respostas (\%) }\end{array}$ \\
\hline Aração, nivelamento, sulcado e gradagem & 20,83 \\
Aração, nivelamento, sulcado, subsolagem e gradagem & 17,74 \\
Nivelamento, sulcado e gradagem & 15,00 \\
Nivelamento, sulcado, subsolagem e gradagem & 9,64 \\
Subsolagem e gradagem & 7,14 \\
Nivelamento, sulcado, subsolagem & 6,67 \\
Aração, nivelamento, sulcado e subsolagem & 4,17 \\
Sulcado e gradagem & 4,17 \\
Aração, sulcado e gradagem & 3,57 \\
Aração, subsolado e gradagem & 3,57 \\
Nivelamento e sulcado & 2,50 \\
Aração e sulcado & 2,50 \\
Sulcado, queima, subsolagem e gradagem & 2,50 \\
Queima & 0,00 \\
\hline
\end{tabular}

Fonte: Dados obtidos nas entrevistas.

Um grande número de entrevistados prefere os adubos do tipo mineral químico $(86,79 \%)$, principalmente pelas características vantajosas que oferecem e pela facilidade de acceso ao produto fornecido pela Cooperativa ou Associação de fornecedores (58,93\%). Na atualidade existem diversas formulações específicas para a cultura da cana-de-açúcar, as quais são recomendadas dependendo das análises de solo e da época de aplicação na 
cultura. Nesse último aspecto, verifica-se que a maioria dos fornecedores $(69,52 \%)$ realiza adubação no sulco de plantio e em cobertura logo após, com adubo nitrogenado, e adubação da soqueira (Tabelas 5 e 6). Nenhum dos fornecedores entrevistados realiza somente a adubação no sulco de plantio ou combinada com cobertura com adubo nitrogenado ou somente na soqueira.

Tabela 5. Percentual médio do tipo de adubação utilizado de acordo com o número respostas

\begin{tabular}{lc}
\hline \multicolumn{1}{c}{ Item do questionário } & Número de respostas (\%) \\
\hline Mineral química & 86,79 \\
Orgánica e mineral química & 13,21 \\
Orgânica & 0 \\
Mineral natural & 0 \\
\hline
\end{tabular}

Fonte: Dados obtidos nas entrevistas

Tabela 6. Percentual médio da quantidade de fornecedores que realizam a adubação nas diferentes épocas recomendadas Item do questionário Número de respostas (\%)

\begin{tabular}{lc}
\hline Plantio, cobertura e soqueira & 69,52 \\
Plantio e soqueira & 30,48 \\
Plantio & 0,00 \\
Plantio e cobertura & 0,00 \\
Soqueira & 0,00 \\
\hline
\end{tabular}

Fonte: Dados obtidos nas entrevistas.

A Tabela 7 deixa claro o papel da Cooperativa dos Plantadores de Cana do Estado de São Paulo - COPLACANA, como importante provedora de materiais e insumos para os fornecedores. Esta oferece facilidades de pago aos serviços e produtos específicos para o setor, o que evidencia-se na 
percentagem acima da metade das respostas obtidas a través dos questionários.

Tabela 7. Percentual médio da quantidade de fornecedores de acordo com a origem dos produtos utilizados

\begin{tabular}{lc}
\hline \multicolumn{1}{c}{ Item do questionário } & Número de respostas (\%) \\
\hline COPLACANA & 58,93 \\
Industria & 26,67 \\
COPLACANA e indústria & 7,74 \\
Outros & 6,67 \\
Usina & 0,00
\end{tabular}

Fonte: Dados obtidos nas entrevistas.

O principal componente do pacote tecnológico, utilizado pelos fornecedores entrevistados, é a seleção de variedades resistentes, as quais oferecem garantias de diminuir os custos de produção, com a mínima aplicação de defensivos agrícolas (Tabela 8). $O$ alto risco que o ataque de pragas e doenças representa nas lavouras canavieiras, uma vez que em diverssas ocasiões no passado recente ocorreu de uma variedade ser praticamente dizimada por enfermidade, faz com que a atenção dos plantadores quanto à resistência ou tolerância à doenças e pragas seja muito importante. Por essa razão, a adoção de variedades resistentes é uma preocupação constante.

A queima continua sendo uma técnica muito difundida nas regiões visitadas, mesmo que esta prática não solucione completamente os problemas posteriores dos tratos culturais, e que esteja com seu uso limitado pela nova legislação. Por outro, a legislação leva em consideração as particularidades dos pequenos fornecedores, que estão contemplados com exigências diferenciadas. Assim, as áreas desses fornecedores tem menos restrições para a utilização da 
queima, como método de despalha da cana-de-açúcar, quando apresentarem alta declividade e menores dimensões das propriedades rurais (Tabela 8).

Aparece também na Tabela 8, a rotação de culturas, na reforma do canavial, como uma prática aceita em alguns casos, principalmente pelas vantagens que oferece na reposição de materia orgância, além da diversificação dos produtos de renda e produção de forragens para a atividade pecuária dos fornecedores. A rotação de culturas apresenta muitas vantagens agronômicas, econômicas, políticas e sociais, mais a sua adoção é dependente da assistência técnica proporcionada ao fornecedor, e do manejo apropriado das plantas daninhas com herbicidas (Monteiro \& Ferreira, 1986; Rodrigues, 1987).

Tabela 8. Percentual médio da quantidade de fornecedores que realizam algumas técnicas de manejo da cultura da cana

\begin{tabular}{lc}
\hline \multicolumn{1}{c}{ Item do questionário } & Número de respostas (\%) \\
\hline Var. Resistentes e queima & 47,02 \\
Var. Resistentes, queima e rotação & 31,31 \\
Var. Resistentes & 15,00 \\
Variedades, associação de culturas e & \\
queima & 4,17 \\
Adubos verdes, variedades e rotação & 2,50 \\
Plantio direto & 0,00 \\
\hline
\end{tabular}

Fonte: Dados obtidos nas entrevistas.

Considerando o longo tempo do início da difusão das práticas de conservação do solo, o nível de adoção apresenta-se muito baixo, correspondendo isto à pouca importância que os fornecedores visitados demostram às vantagens dos sistemas de produção conservacionistas, como o controle da erosão, que nestas áreas é necessário. Essas práticas de 
conservação se fazem particularmente importantes em uma região como a de Piracicaba, onde a grande maioria dos solos é suscetível à erosão e situa-se em paisagem com relevo ondulado e vertentes com declividade acentuada (Sparovek, 1997). A conseqüência desta mentalidade é o reduzido interesse demonstrado pela maioria dos entrevistados em conhecer algumas alternativas de produção que implicassem na introdução de espécies perenes que contribuírem com o controle da erosão do solo, como por exemplo os SAFs, nas áreas com maior percentagem de declividade (Tabela 9).

Tabela 9. Percentual médio da quantidade de fornecedores que realizam práticas de conservação do solo

\begin{tabular}{lc}
\hline \multicolumn{1}{c}{ Item do questionário } & $\begin{array}{c}\text { Número de } \\
\text { respostas (\%) }\end{array}$ \\
\hline C. de nível, terraceamento e proteção de fontes de água & 45,71 \\
Curvas de nível e terraceamento & 22,74 \\
Proteção de fontes de água e culturas em faixas & 11,07 \\
Proteção de fontes de água e terraceamento & 10,83 \\
Curvas de nível & 3,57 \\
Proteção de fontes de água & 3,57 \\
C. de nível, terraceam., culturas em faixas e proteção & 2,50
\end{tabular}

Fonte: Dados obtidos nas entrevistas.

Evidente é a preferência dos fornecedores entrevistados na Associação para realizar as análises de qualidade industrial, etapa de grande importancia, principalmente devido à confiabilidade oferecida pela equipe técnica que representa à classe, nas negociações com o setor industrial e governamental. 
Tabela 10. Percentual médio dos fornecedores de acordo com o critério utilizado para a colheita da cana-de-açúcar

\begin{tabular}{lc}
\hline \multicolumn{1}{c}{ Item do questionário } & Número de respostas (\%) \\
\hline Análise na AFOCAPI & 41,90 \\
AFOCAPI e análise na usina & 18,81 \\
Entrada na usina & 12,74 \\
Idade da cana e entrada na usina & 11,07 \\
Análise na usina & 7,74 \\
AFOCAPI e idade da cana & 7,74
\end{tabular}

Fonte: Dados obtidos nas entrevistas.

A maioria dos entrevistados continua com a prática da queima da palha, contrariando às recomendações técnicas de manter o palhiço cubrindo as entrelinhas, tentando manter o maior tempo possível a cobertura do solo, o que ajuda no controle de plantas daninhas, reduzindo as aplicações de herbicidas, no controle da erosão dos talhões, e pode contribuir para aumentar a matéria orgância do solo.

O enleiramento é uma operação indispensável para os fornecedores de cana-de-açúcar visitados, principalmente devido a que facilita o cultivo e a adubação posterior da soqueira, e favorece a brotação do seguinte ano. Mais da metade dos fornecedores entrevistados realiza o enleirado com queima (Tabela 11). 
Tabela 11. Percentual médio dos fornecedores de acordo com o destino da palha depois da colheita da cana-de-açúcar

\begin{tabular}{lc}
\hline \multicolumn{1}{c}{ Item do questionário } & Número de respostas (\%) \\
\hline Enleirada com queima & 65,36 \\
Enleirada sem queima & 19,41 \\
Espalhada & 9,17 \\
Queima & 6,07 \\
\hline
\end{tabular}

Fonte: Dados obtidos nas entrevistas.

Todos os fornecedores visitados trabalham em dependência da mão-de-obra familiar e temporária. Considerando que a atividade principal é a produção de cana-de-açúcar, foram achadas várias famílias com antiga tradição na produção canavieira, onde os conhecimentos técnicos e de gerenciamento são transmitidos de geração a geração. A mão-de-obra permanente empregada nas propriedades visitadas são principalmente os que tem a função de operários de maquinárias, os que cuidam da produção pecuária simultáneamente com a de cana-de-açúcar, os responsáveis pela industrialização da matéria-prima na destilaria, e os funcionários mais antigos e de confiança. No que refere-se à mão-de-obra contratada temporáriamente, são as atividades braçais, como o plantio e o corte manual da cana, as principais empregadoras nas épocas de maior demanda (Tabela 12).

Tabela 12. Percentual médio dos fornecedores de acordo com o tipo de mãode-obra empregada na produção da cana-de-açúcar

\begin{tabular}{cc}
\hline Item do questionário & Número de respostas (\%) \\
\hline Familiar, permanente e temporária & 55,36
\end{tabular}


Familiar e temporária 44,65

Familiar

0,00

Familiar e permanente

0,00

Fonte: Dados obtidos nas entrevistas.

Na Tabela 13 são apresentadas as respostas dos entrevistados ao respeito das dificuldades atuais no sistema de produção de cana-de-açúcar, onde podemos salientar que o controle do mato é o principal problema, isto obedece à falta de conhecimento profundo dos métodos de controle, e especialmente da biologia das plantas daninhas que infestam os canaviais. $O$ método de controle químico, é muito utilizado, mais a deficiência no manejo traz consequências que escapam das possibilidades de solução no momento apropriado para a cultura da cana-de-açúcar. Os outros problemas mencionados pelos fornecedores não correspondem aos temas técnicos, mais afetam diretamente ao sistema de produção, como por exemplo os aspectos trabalhistas, as dificuldades para contratar mão-de-obra na época da reforma do canavial. Salientam também os problemas ocasionados devido à dependencia da usina, no momento da colheita, e que as vezes prejudica o rendimento industrial da materia-prima produzida pelo fornecedor.

Tabela 13. Freqüência dos fornecedores entrevistados segundo os principais problemas com a prática agronômica que dificultam a produção de cana-de-açúcar

\begin{tabular}{lc}
\hline \multicolumn{1}{c}{ Item do questionário } & Número de respostas \\
\hline Controle de plantas daninhas & 6 \\
Outros & 6 \\
Falta de informações e conhecimentos técnicos & 5 \\
Falta de máquinas e equipamentos & 4 \\
Controle de pragas e doenças & 4
\end{tabular}


Nenhum

Dificuldades na programação da produção

Falta de experiência com a cultura

Dificuldade de obter insumos
1

Fonte: Dados obtidos nas entrevistas.

A importância das variedades, no sistema de produção da cana-deaçúcar, aparece na Tabela 14, também nas prioridades de temas a serem pesquisados pelos técnicos especialzados em melhoramento genético, principalmente. Considerando a evolução das variedades anteriormente mencionadas, podemos indicar que quando uma variedade apresenta características interesantes para o fornecedor, ele as adota e modifica rápidamente suas áreas, sempre na procura de maiores produtividades com menores custos. Além disso, as dificuldades para a mecanização das áreas mais declivosas e de menor dimensão, preocupa e seria uma tecnologia a ser desenvolvida pelas instituções de pesquisa com a colaboração das industrias de maquinárias em implementos. Um outro aspecto foi a degradação dos solos observada pelos fornecedores, e que obriga à busca de soluções adaptadas às condições locais, para recuperar à capacidade produtiva dos solos da região, devido a que continuando com o sistema de adubação atual, as respostas diminuim gradativamente, prejudicando a rentabilidade da atividade.

Tabela 14. Freqüência dos fornecedores entrevistados segundo os aspectos técnicos mais importantes para serem resolvidos pela pesquisa em cana-de-açúcar

\begin{tabular}{lc}
\hline \multicolumn{1}{c}{ Item do questionário } & Número de respostas \\
\hline Estudo de variedades adaptadas & 15 \\
Desenvolvimento de máquinas e equipamentos & 6 \\
Manejo da matéria-orgânica e fertilidade do solo & 6 \\
Controle de plantas daninhas & 5
\end{tabular}


Outros

Métodos eficientes para planejar a colheita

Controle de pragas e doenças

Adubos verdes

0

Fonte: Dados obtidos nas entrevistas.

\subsection{Sistema de uso da terra}

Uma das características para a seleção dos fornecedores foi que trabalhasse na área própria, devido a que sendo ele mesmo o dono da terra teria maior facilidade no momento da decissão de adotar uma nova tecnologia. Os fornecedores entrevistados que são afetados com a nova legislação, específicamente no referente às mudanças no sistema de colheita da cana-deaçúcar, devem tomar a decissão de incorporar novos conhecimentos, novas tecnologías, para continuar com a produção da cana ou optar por outras atividades indicadas para sua realidade.

Com o arrendamento de terras adicionais para a produção de canade-açúcar evidenciam-se as limitações de áreas disponíveis para a expansão da cultura nestas regiões. Os fornecedores com capacidade econômica para arrendar terras teriam a possibilidade de cancelar os contratos se em algúm momento a situação do setor o levasse a desistir da atividade. A alta rentabilidade da producção da cana faz com que o investimento em arrendamento vale a pena. Mais da metade dos entrevistados, além das terras próprias, também trabalham em terras arrendadas, nessa áreas é difícil a adoção devido à longa duração do sistema, o que precisa de longo prazo para obter resultados de produção. 
Para a adoção de SAF, é preciso que o fornecedor seja dono da terra, isto facilitaria a mudança do sistema de produção nas áreas restritas à mecanização da colheita, realizando um investimento a longo prazo e com a possibilidade de aprimorar as técnicas de manejo no período de instalação e maturação do sistema.

A principal limitação do sistema de produção dos fornecedores entrevistados, é a reduzida possibilidade de expansão da atividade nas áreas próximas à propriedade, isto acarreia o incremento dos custos de produção com o desplazamento de todos os recursos, seja maquinárias ou mão-de-obra, a grandes distancias do local.

Tabela 15. Porcentual médio de fornecedores de cana-de-açúcar segundo posse da terra

\begin{tabular}{lc}
\hline \multicolumn{1}{c}{ Item do questionário } & Número de respostas (\%) \\
\hline Própria & 51,79 \\
Própria e arrendada & 39,64 \\
Própria, arrendada e tercerizada. & 8,57 \\
\hline
\end{tabular}

Fonte: Dados obtidos nas entrevistas.

A maioria dos entrevistados aproveitam as áreas declivosas para a produção pecuária, com pastagens e gado bovino, sendo a principal atividade de renda depois da cana-de-açúcar. Na Tabela 16, são incluidas também a distribuição do aproveitamento do solo, incluindo as áreas exigidas pela legislação ambiental no que refere-se ao manejo e conservação. A região onde localiza-se o estudo apresenta uma topografia movimentada, associada a um grande número de pequenas bacias hidrográficas, implicando na ocorrência freqüente e constante de cursos d'água. Como conseqüência, era de se esperar uma maior percentagem de fornecedores que tivessem áreas ocupadas reserva ambiental de Preservação Permanente. Verifica-se que somente uma pequena 
fração dos fornecedores entrevistados, 9 em 25, possuíam alguma área com Preservação Permanente. Ao percorrer as propriedades, na ocasião das entrevistas, constatou-se em diversos casos, locais onde tipicamente deveria haver Áreas de Preservação Permanente. Ademais, um fração menor ainda dos fornecedores possui áreas com Reserva Legal.

As culturas anuais, como a soja e o milho, contribuim com a renda da família, e em alguns casos são localizados em áreas restritas para a canade-açúcar, por exemplo sob as linhas de alta tensão, onde existem limitações de altura de cultura e restrições rígidas contra a queima, na produção agrícola nessas áreas.

Tabela 16. Frequência das respostas dos fornecedores segundo a diversificação da produção e uso do solo dentro da propriedade rural

\begin{tabular}{lc}
\hline \multicolumn{1}{c}{ Item do questionário } & Número de respostas (\%) \\
\hline Pastagens & 22 \\
Bovinos & 22 \\
Aves & 17 \\
Mata ciliar & 12 \\
Milho & 11 \\
Preservação Permanente & 9 \\
Suínos & 6 \\
Reflorestamento & 5 \\
Reserva legal & 3 \\
Laranja & 2 \\
Soja & 1 \\
Nascentes & 1 \\
Feijão & 0 \\
\hline
\end{tabular}

Fonte: Dados obtidos nas entrevistas. 
Mais da metade dos fornecedores entrevistados apresentaram problemas para adotar a colheita mecanica, o que pode ser apreciado na Tabela 17, onde somente algumas áreas estão utilizando ou poderiam aproveitar esta tecnologia, apropriada para áreas com declividades permitidas operacionalmente na atualidade. Outras características associadas à declividade que prejudicam o trabalho eficiente das colheitadeiras, a localização em áreas isoladas, não contíguas, inferiores a 250 hectares, e de difícil acceso.

Tabela 17. Percentual médio dos fornecedores que possuem área com declividade acima de $12 \%$ o que dificulta a colheita mecánica

\begin{tabular}{cc}
\hline Item do questionário & Número de respostas (\%) \\
\hline Com problemas para a colheita mecânica & 64,29 \\
Sem problemas para a colheita mecânica & 35,72 \\
\hline
\end{tabular}
Fonte: Dados obtidos nas entrevistas.

\subsection{Outras atividades}

Todos os entrevistados apresentam uma tradição na atividade canavieira desde várias gerações anteriores, na Tabela 18 é evidente que a continuidade na produção de cana-de-açúcar está fortemente influenciada pela herança de terras, de conhecimentos e de bens relacionados ao setor.

Tabela 18. Indicadores da importância da atividade canavieira para os fornecedores entrevistados

\begin{tabular}{cc}
\hline Item do questionário & Número de respostas \\
\hline Pretende continuar plantando cana & 25 \\
Acima de 20 anos como fornecedor & 24
\end{tabular}


Atividade anterior

18

Fonte: Dados obtidos nas entrevistas.

Ainda com a produção de cana-de-açúcar como principal fonte de renda, existem outras atividades que contribuem com os ingresos do fornecedor, principalmente a pecuária. Na Tabela 19 são apresentadas as respostas obtidas nas entrevistas realizadas, salientando a nova tendência de atividades alternativas, dependendo dos recursos econômicos ou naturais, da experiência, e da visão de exploração de serviços dos fornecedores.

Tabela 19. Frequência das outras atividades de renda adicionais dos fornecedores entrevistados

\begin{tabular}{lc}
\hline \multicolumn{1}{c}{ Item do questionário } & Número de respostas \\
\hline Venda de animais & 11 \\
Serviços a terceiros & 10 \\
Destilaria & 3 \\
Turismo rural & 2 \\
Venda de mudas cítricas & 1 \\
\hline
\end{tabular}

Fonte: Dados obtidos nas entrevistas.

Podemos assegurar que nas respostas da Tabela 20, dentre as outras alternativas mencionadas pelos entrevistados, estão o invetimento em tecnologia para aumentar a produtividade na mesma área, sem ter a necessidade de comprar mais terra ou abandonar a atividade, e na atividade pecuária, que apresenta-se como uma ótima alternativa de produção nas áreas com restrições à mecanização, além de ter a facilidade de manejo. Outra opção seria a industrialização artesanal da cana-de-açúcar e a diversificação de atividaes na área rural. A importância de contratar a profissionais técnicos 
capacitados para o manejo da área, evidencia a falta de conhecimentos técnicos adequados à realidade do fornecedor e às exigencias atuais do setor.

Tabela 20. Freqüência das respostas emitidas em relação à intenção de investimento do entrevistado

\begin{tabular}{lc}
\hline \multicolumn{1}{c}{ Item do questionário } & Número de respostas (\%) \\
\hline Outros & 12 \\
Aquisição de terras para a expansão da cana & 10 \\
Plantio de outras culturas & 7 \\
Compra de máquinas e implementos & 6 \\
Moradia (ampliação, melhoria, etc.) & 5 \\
Ampliar a produção de cana-de-açúcar & 4 \\
Renovação de variedades & 2 \\
Aquisição de bens domésticos & 1 \\
Aquisição de veículos & 1 \\
Mudaria para a cidade & 0 \\
\hline
\end{tabular}

Fonte: Dados obtidos nas entrevistas.

A visão dos entrevistados é muito clara, devido à tradição, às reduzidas alternativas e aos incentivos economicos do setor, a continuidade na produção de cana-de-açúcar pretende seguir sendo a principal atividade por enquanto. Nas Tabelas 21 e 22, a maioria dos fornecedores irá manter as áreas plantadas com cana, e uma percentagem menor aumentará, na medida de sua disponibilidade de terra e capacidade de produção.

Tabela 21. Percentual médio das perspectivas de produção de cana-de-açúcar dos fornecedores 


\begin{tabular}{lc}
\hline$\quad$ Item do questionário & Número de respostas (\%) \\
\hline Manterá & 66,55 \\
Aumentará & 33,45 \\
Diminuirá & 0
\end{tabular}

Fonte: Dados obtidos nas entrevistas.

Tabela 22. Percentual médio dos fatores que influenciam as perspectivas de produção

\begin{tabular}{lc}
\hline \multicolumn{1}{c}{ Item do questionário } & Número de respostas (\%) \\
\hline Área disponível & 74,88 \\
Outros & 21,55 \\
Preço & 3,57 \\
Usina & 0,00
\end{tabular}

Fonte: Dados obtidos nas entrevistas.

\subsection{Nível de conhecimento da legislação ambiental}

A totalidade dos entrevistados nas visitas realizadas responderam afirmativamente a todas a consultas relacionadas com a legislação ambiental, específicamente ao conhecimento detallado das restrições impostas ao setor, como as proibições na utilização da queima, as áreas próximas das fontes de água (rios, nascentes, reservorios), de caminhos, de cidades, de aeroportos, de linhas de transmissão de energia elétrica, sub-estações de energia eletrica, gaseodutos e oleodutos, estações de telecomunicações, ferrovias, rodovias, estações ecológicas, parques públicos e áreas naturais. As medidas de segurança em casos de incêndios criminosos ou derivados de força maior. 
Algumas opiniões podem ser citadas como a de sugerir ao governo, incluir incentivos apropriados ao setor para a continuidade da produção da cana-de-açúcar, para evitar o éxodo rural desta áreas para as cidades.

\subsection{Alternativas para áreas não mecanizáveis}

Verifica-se que o nível de conhecimento sobre SAFs é muito baixo. Somente $12 \%$ conhecem ou ouviram informações sobre o asunto. Alegam que faltam resultados de pesquisa concretos, confiáveis, comprovados localmente e adaptados aos tipos de solo da região, para motivá-los.

Tabela 23. Nível de conhecimento sobre Sistemas Agroflorestais de acordo com o número de respostas dos fornecedores entrevistados

\begin{tabular}{lc}
\hline \multicolumn{1}{c}{ Item do questionário } & Número de respostas (\%) \\
\hline Adotaria se houvesse resultados & 36 \\
Tem algum conhecimento sobre SAF & 12 \\
Imagina que seria sustentável & 12 \\
Conhece resultados de pesquisa & 8 \\
\hline Obs.: As respostas aos indicadores tem por base o número de fornecedores \\
entrevistados (25), considerando que algumas perguntas possibilitam \\
respostas múltiplas, os percentagens não totalizam o cem percento.
\end{tabular}

\subsection{Entraves para a adoção de Sistemas Agroflorestal}


Dentre os problemas tecnológicos para adoção de SAFs destacaramse a dificuldade para obter informações e assistência técnica, especialmente sobre manejo e planejamento, a falta de experiência própria, e da mão-de-obra contratada nesses sistemas. Preocupam também os possíveis efeitos negativos das árvores na cultura da cana-de-açúcar.

Os possíveis entraves para a comercialização dos produtos dos SAFs e a disponibilidade de insumos específicos para essa nova atividade seriam razões fortes para não adotar o sistema de produção alternativo.

Comparando o mercado da cana, que apesar de depender da usina local em um regime de oligopólio possui uma certa estabilidade e segurança, com o de outros produtos testados (ex. tomate e girasol) que são muito mais complicados, exigem conhecimentos específicos para a comercialização da produção e para os quais não existe uma malha de recepção e compra.

Os aspectos financeiros não se mostram relevantes para os fornecedores, que não alegam falta de crédito como difuculdade para adotar SAFs e que estariam dispostos a investir recursos próprios caso estes se mostrassem económica e técnicamente viáveis.

Tabela 24. Entraves para a adoção de Sistemas Agroflorestais de acordo com o número de respostas dos fornecedores entrevistados

Item do questionário Número de respostas (\%)

1. Aspectos tecnológicos

a. Falta informações e assistência técnica 36

b. Falta de experiência própria 28

c. Falta de mão-de-obra capacitada 28

d. Efeitos negativos na produção de cana 4

2. Aspectos da comercialização 
a. Entraves para comercializar a produção

3. Aspectos financeiros

a. Necessidade de investimento inicial

8

b. Ausência de crédito agrícola específico

4

Obs.: As respostas aos indicadores tem por base o número de fornecedores entrevistados (25), considerando que algumas perguntas possibilitam respostas múltiplas, os percentagens não totalizam o cem percento.

Influenciam positivamente na decisão de adoção de SAFs a comprovação de melhor conservação dos recursos naturais e a economicidade dos sistemas.

Tabela 25. Razões do Fornecedor que influenciariam sua decisão de adotar Sistemas Agroflorestais de acordo com o número de respostas dos fornecedores entrevistados

\begin{tabular}{lc}
\hline \multicolumn{1}{c}{ Item do questionário } & Número de respostas (\%) \\
\hline 1. Conservação de recursos naturais & 24 \\
2. Razões econômicas & 20 \\
3. Política atual & 16 \\
4. Saúde da comunidade & 8 \\
5. Melhorar a produtividade & 8 \\
4. Saúde pessoal e da família & 4 \\
5. Saúde do consumidor & 4 \\
6. Convição ideológica & 4
\end{tabular}

Obs.: As respostas aos indicadores tem por base o número de fornecedores entrevistados (25), considerando que algumas perguntas possibilitam respostas múltiplas, os percentagens não totalizam o cem percento.

Quanto aos meios de difusão de informações preferem a AFOCAPI e em segundo lugar os programas emitidos atraves da televisão, porém são 
também relevantes cursos e palestras isolados, as informações originadas nas usinas e difundidas através de entrevistas, visitas e contatos com os técnicos dessas usinas. Nota-se que os organismos oficiais de assistência técnica são pouco considerados pelos fornecedores. Consideram os aspectos econômicos e as técnicas de produção os temas de maior interesse.

Tabela 26. Aspectos da difusão tecnológica de acordo com o número de respostas dos fornecedores entrevistados

\begin{tabular}{cc}
\hline Item do questionário & Número de respostas (\%) \\
\hline
\end{tabular}

1. Origem ou meios de difusão

a. AFOCAPI 68

b. Televisão 44

c. Cursos e palestras isolados 36

d. Usina compradora de cana 32

e. Internet 20

$\begin{array}{ll}\text { f. Jornal } & 16\end{array}$

g. Outros fornecedores 16

h. Prefeitura e CATI 8

2. Temas de interesse

a. Econômicos 56

b. Técnicas de produção 52

c. Ambientais 28

d. Institucionais 24

e. Sociais e culturais $\quad 12$

Obs.: As respostas aos indicadores tem por base o número de fornecedores entrevistados (25), considerando que algumas perguntas possibilitam respostas múltiplas, os percentagens não totalizam o cem percento. 


\subsection{Complexo agroindustrial da cana-de-açúcar}

Para a redução da área com cana na região e, consequentemente sua produção, opinada em $84 \%$ das respostas recebidas, as possíveis soluções seriam a expansão da cultura da cana-de-açúcar para áreas sem restrições à mecanização, o aumento da produtividade em toneladas por hectare e a manuntenção da cultura em áreas declivosas com a disponibilidade de mão-deobra barata para o corte manual da cana crua. A adoção de SAFs, após resultados positivos de áreas experimentais comprovando sua economicidade apareceu em somente $8 \%$ das respostas.

Como alternativas produtivas e tecnológicas, foram citadas a implantação de pastagens nas áreas declivosas e o melhoramento e adaptação das colhedoras para o corte da cana em declividades pronunciadas.

Tabela 27. Consequências da proibição da queima de acordo com o número de respostas dos fornecedores entrevistados

$$
\text { Item do questionário }
$$

Número de respostas (\%)

1. Haverá redução da área de cana

a. $\operatorname{Sim}$

b. Não

8

c. Depende da mão-de-obra para o corte

8

2. Cómo solucionaría este problema

a. Expansão em áreas sem restrições

b. Aumentando a produtividade

c. Continuar em áreas declivosas

d. Adoção de SAFs

e. Dispondo de colhedoras adequadas

f. Implantação de pastagens 
Obs.: As respostas aos indicadores tem por base o número de fornecedores entrevistados (25), considerando que algumas perguntas possibilitam respostas múltiplas, os percentagens não totalizam o cem percento.

Assim, para um programa de implantação de SAFs como tecnologia alternativa para o uso de áreas declivosas atualmente ocupadas com cana-deaçúcar, tais principios devem ser levados em consideração, e todo o processo precissa ser desenvolvido com métodos participativos e o efetivo envolvimento dos fornecedores.

\subsection{Considerações complementares}

Os resultados apresentados nas Tabelas 8 e 14 indicam que, dentro dos diversos aspectos ou componentes do sistema de produção, aquele que os fornecedores mais tem em conta é a adoção de variedades apropriadas e adaptadas ao seu local, e que sejam produtivas e tolerantes às adversidades da cultura.

A importância dada pelos fornecedores ao item variedade e o fato de que a maior parte das mudas são oriudas das usinas indicam a grande confiabilidade que esses tem na usina, apesar das variedades serem originalmente produzidas pelos programas de melhoramento de instituições, como UFSCar-RIDESA, Copersucar, IAC, solidamente estabelecidas no cenário tecnológico do setor sucroalcooleiro. A proximidade, seja em distância, seja em similaridade de condições edafo-climáticas, é o fator preponderante que determina esse intercâmbio de tecnologia. Somado a isso, o financiamento da muda oferecido pela usina, facilita ainda mais a apropriação da tecnologia. 
Pelos resultados apresentados nas Tabelas 2 e 26, verifica-se que a usina compradora do produto é uma das principais fontes de tecnologia. Já, os resultados das Tabelas 23 e 24 mostram que a principal motivação para adoção de SAFs seria a existência de resultados positivos comprovados no campo e o apoio de divulgação da informação e de assistência técnica. Ter a usina como uma referência para tecnologia indica que os fornecedores necessitam de exemplos concretos demonstráveis para tomar a iniciativa de modificar o seu próprio sistema de produção. Esse comportamento deve estar ligado a uma tentativa de redução dos riscos. Adicionalmente, os fornecedores não dispõem de área agricultável para realização de testes na escala espacial demandada para uma experiência com SAFs, que sabidamente precisam ser estudados em parcelas muitas vezes de tamanho superior a alguns hectares para poderem apresentar resultados visualizáveis. 


\section{CONCLUSÕES}

Os principais entraves para a adoção de Sistemas Agroflorestais, pelos fornecedores de cana-de-açúcar da região de Piracicaba são o desconhecimento dos princípios e das vantagens que um sistema como este oferece, e a falta de comprovação a nível local de resultados positivos dos SAFs.

Quando algumas explicações são dadas, os fornecedores se interessam pelas possibilidades de aproveitar melhor as áreas declivosas que poderiam ser produtivas com a instalação de SAFs. Também, não demonstra resistência natural à mudança tecnológica. Os entraves para a adoção, não são intrínsecos aos fornecedores, mas são principalmente devido às características da própria tecnologia. Nesse caso, as maiores preocupações são a adaptabilidade da tecnologia às diferentes condições dos fornecedores, a segurança do mercado para os produtos, e existência de um programa oficial de assistência técnica e treinamento de mão-de-obra.

Os fornecedores contam com o capital para investir, se a alternativa tecnológica for comprovadamente rentável. Porém, tem uma aversão ao risco financeiro para investimentos a longo prazo. Assim, a ajuda financeira é necessária para diminuir o risco. Dessa forma, o principal impedimento para a adoção de SAFs é a ausência de comprovação concreta das vantagens agronômicas e econômicas desses sistemas de uso do solo. 


\section{REFERÊNCIAS BIBLIOGRÁFICAS}

ASSOCIAÇÃO DOS FORNECEDORES DE CANA-DE-AÇÚCAR DE PIRACIABA. Censo varietal quantitativo 2000-2001. Canavieiro Paulista. v.14, n. 76, p.4. Jan-Fev. 2001.

ALEXIO, S.S.; SOUZA, J.G. Análise do nível tecnológico de fornecedores de leite:

estudo de caso da Cooperativa Nacional Agroindustrial (CONAl), Ribeirão Preto (SP). Informações Económicas, v.31, n.10, p.27-36, 2001.

BANCO DO BRASIL. Sucroalcooleiro. BB Panorama Setorial. v. 9, n.81, março, 2000. p.39-42.

BASALDI, O.V. Inovações tecnológicas e mudanças no processo de trabalho em culturas de importância econômica no Estado de São Paulo. SOBER, n.32, p.425-440, 1994.

BERNARDES, M.S.; SPAROVEK, G. Sistemas de produção para áreas com restrições à colheita mecanizada de cana-de-açúcar. Projeto de pesquisa. Depto. de Agricultura e Ciência do Solo - Piracicaba, 1998a. 27p.- Escola Superior de Agricultura "Luiz de Queiroz", Universidade de São Paulo. 
BERNARDES, M.S.; SPAROVEK, G.; ROSSETTO, R.; FARAHT, M.; VICCINO, J.R.; STAPE, J.L.; FILHO, V.A.C.; HAMMERSCHLAG, N. Sistemas de produção para áreas com restrições à colheita mecanizada de cana-deaçúcar. In: SEMANA DE CANA-DE-AÇÚCAR DE PIRACICABA, 3., Piracicaba, 1998. Anais. Piracicaba: STAB, 1998b. p.35-37.

CÂMARA PAULISTA DO SETOR SUCROALCOOLEIRO. http://www.orplana.com.br . (18 mar. 2002).

CÂMARA PAULISTA DO SETOR SUCROALCOOLEIRO. http://www.orplana.com.br/resultsafra4.htm. (1 fev. 2004).

CARON, D. Heterogeneidade e diferenciação dos fornecedores de cana de SP. São Paulo, 1986. Tese (Doutorado) - Faculdade de Filosofia e Ciências Humanas, Universidade de São Paulo.

CHAPMAN, J. A. Design and evaluation of new technologies for adoption by small farmers: an example from the Philippines. In: FARMING SYSTEMS RESEARCH SYMPOSIUM, Manhattan, 1983. Animals in the farming systems: Proceedings. Manhattan: Kansas State University, 1984. p.604623. (Kansas State University. Farming Systems Research Paper, 6).

COOPERATIVA DE FORNECEDORES DE CANA, AÇÚCAR E ÁLCOOL DO ESTADO DE SÃO PAULO LTDA. Censo varietal 2002. Centro de tecnologia Copersucar. Coordenadoria do programa de variedades. Jul. 2003. $16 p$. 
COOPERATIVA DE FORNECEDORES DE CANA, AÇÚCAR E ÁLCOOL DO ESTADO DE SÃO PAULO LTDA. Boletim técnico. Edição Especial. Quarta geração de variedades de cana-de-açúcar Copersucar. Coordenadoria do programa de variedades. Dez. 1993. s.n.p.

CURRENT, D.; LUTZ, E.; SCHERR, S.J. Costs, benefits, and farmer adoption of agroforestry: lessons from project experience in Central America and Caribbean. Dissemination Notes Toward Environmentally and Socially Sustainable developments. Washington: World Bank, 1996. 4p. (World Bank Environment Paper, 33).

DAROLT, M. R. As Dimensões da sustentabilidade: Um estudo da agricultura orgânica na região metropolitana de Curitiba, Paraná. Curitiba, 2000. 310p. Tese (Doutorado)-Universidade Federal do Paraná.

DUBOIS, J.C.L. SAF em relevo acidentado. In: WORKSHOP NACIONAL DE AGRICULTURA SUSTENTÁVEL EM REGIÕES TROPICAIS DE RELEVO ACIDENTADO (compact disc), 3., Paty do Alferes, RJ, 1997. Anais. Rio de Janeiro: EMBRAPA CNPS, 1998. (Boletim de Pesquisa, 9).

EID, F. Progresso técnico na agroindústria sucroalcooleira. Informações Econômicas, v.26, n.5, p.29-36, maio. 1996.

FNP CONSULTORIA \& COMERCIO. Agrianual 2004: Anuário da agricultura brasileira. São Paulo, 2003. 496p.

FRANZEL, S. Socioeconomic factors affecting the adoption potential of improved tree fallows in Africa. Agroforestry Systems, v. 47, p. 305-321, 1999. 
FRIAS MORÁN, H.; RAMSAY ARCE, J.; BELTRAN, L.R. Extension agrícola: princípios y técnicas. Lima: Instituto interamericano de ciencias agricolas de la OEA, 1966. 604p.

GONÇALVES, J.S.; SOUZA, S.A.M. Alternativas econômicas para áreas com restrições à colheita mecanizada da cana-de-açúcar, na região de Piracicaba - SP. In: SEMANA DA CANA-DE-AÇÚCAR DE PIRACICABA 3., Piracicaba, 1998. Anais. Piracicaba: STAB, 1998a. p.4-8.

GONÇALVES, J.S.; SOUZA, S.A.M. Proibição da queima de cana no Estado de São Paulo: simulações dos efeitos na área cultivada e na demanda pela força de trabalho. Informações Econômicas, v.28, n.3, mar. 1998b. p.2140.

GUEDES, S.N.R.; RÉ, R.M. Os determinantes da decisão microeconômica de mecanizar o corte da cana no estado de São Paulo: Um estudo de caso (compact disc). Brasília: SOBER, 1999.

HAISHUI, Z.; KEJUN, H. Intercropping in Rubber plantation and its economic benefit. In: Zhaohua, Z.; Mantang, C.; Shiyi, W.; Youxu, J. (Ed.) Agroforestry systems in China. Ottawa: Chinese Academy of Forestry and International Development Research Centre, 1998. p.204-206.

HEADY, E. O. Basic economic and welfdre aspects of farm technological advance. Journal of Farm Economics, n.31, p.293-316, 1949.

ICRAF. INTERNATIONAL CENTRE FOR RESEARCH IN AGROFORESTRY. http://www.icraf.org/regional/region 4/region 4.htm (18 mar. 2002) 
INSTITUTO BRASILEIRO DE GEOGRAFIA E ESTATÍSTICA. IBGE, DPE, DEAGRO -Levantamento sistemático da produção agrícola. Diretoria de pesquisas, Departamento de agropecuária, produção agrícola municipal). www.ibge.gov.br (4 mar. 2002).

JUNQUEIRA, A.A. B.;.DANTAS, B. A cana-de-açúcar no Brasil. In: Cultura e adubação da cana-de-açúcar. São Paulo: Instituto Brasileiro da Potassa, 1964. p.27-60.

MacDICKEN, K.G.; VERGARA, N.T. Agroforestry: Classification and management. New York: John Wiley, 1990. 382p.

MARTín, N. B. A performance da agricultura no Estado de São Paulo e das suas regiões agrícolas no pós 70. Agricultura em São Paulo, v.39, n.1, p.97-131, 1992.

MONTEIRO, A.O.; FERREIRA, E.S. Projeto rotação de culturas - principais resultados obtidos. In: SEMINÁRIO DE TECNOLOGIA AGRONÔMICA, 3., Piracicaba, 1986. Anais. São Paulo: Copersucar, 1986. p.87-200.

MORAES, M.A.F.D. A desregualmentação do setor sucroalcooleiro do Brasil. Piracicaba, 1999. 292p. Tese (Doutorado) - Escola Superior de Agricultura Luiz de Queiroz, Universidade de São Paulo.

NAIR, P.K.R. Agroforestry systems in the tropics. London: Kluwer, 1989. $664 p$.

NEUMANN, P.S.; LOCH, C. Legislação ambiental, desenvolvimento rural e práticas agrícolas. Ciência Rural, v.32, n.2, p.243-249, 2002. 
PEACH, W.N. Principles of Economics. 8.ed. Illinois: Irwin, 1955. 736p.

PETERSEN, P. Caminhos de uma transição necessária: ação de ONGs na promoção de um novo modelo de desenvolvimento agrícola para o Brasil e os desafios levantados para a pesquisa e o ensino universitário em ciências agrárias (compact disc). In: CONGRESSO BRASILEIRO DE CIÊNCIA DO SOLO 26., Rio de Janeiro, 1997. Anais. Rio de Janeiro: SBCS, 1997.

PINTO, L.F.G. Avaliação do cultivo de cana-de-açúcar em sistemas agroflorestais em Piracicaba - SP. Piracicaba, 1995. 116p. Tese (Doutorado) - Escola Superior de Agricultura "Luiz de Queiroz", Universidade de São Paulo.

PINTO, L.F.G.; BERNARDES, M.S.; SPAROVEK, G.; CÂMARA, G.M.S. Feasibility of Agroforestry for sugarcane production and soil conservation in Brazil. In: STOTT, D.E.; MOHTAR, R.H.; STEINHARDT, G.C. (Ed.). Sustaining the Global Farm. In: INTERNATIONAL SOIL CONSERVATION ORganization MEetING, 10., Purdue, 1999. Select papers. Purdue University., USDA-ARS Nacional Soil Erosion Research Laboratory, 1999. p. 317-320.

PINTO, L.F.G.; BERNARDES, M.S.; NOORDWIJK, M.V.; PEREIRA,A.R.; SPAROVEK, G. Avaliação do cultivo de cana-de-açúcar em sistemas agroflorestais na região de Piracicaba, SP. In: CONGRESSO NACIONAL DA STAB, 8., Pernambuco, 2002. Anais. Pernambuco: STAB, 2002. p.506512.

RAMOS, P. Agroindústria canavieira e propriedade fundiária no Brasil. São Paulo: Hucitec, 1999. 245p. (Economia e Planejamento; 36. Série "Teses e Pesquisas"; 21). 
RAMOS, P. A evolução da agroindústria canavieira paulista no período 19461980: expansionismo agrário e características da estrutura de produção. Informações Econômicas, v.31, n.8, p.21-25, ago. 2001.

RODRIGUES, R. A produção de alimentos em canaviais. In: PARANHOS, S.B., (Coord.) Cana-de-açúcar - cultivo e utilização. Campinas: Fundação Cargill, 1987. v.2, cap. II, p.505-516.

RODRIGUEZ OCAÑA, A; BERBEL VECINO, J.; RUIZ AVIÉS, P. Metodologia para el análisis de la toma de decisions de los agricultures. Madrid: Ministerio de agricultura, pesca y alimentación. Instituto nacional de investigación y tecnologia agraria y alimentaria, 1998. 157p. (Colección Monografias INIA, 101).

ROGERS, E.; HAVENS, E. Adoption of hybrid corn profitability versus the interaction effect. Rural Sociology, n.26, v.4, p.409-414, Dec. 1961.

ROLIM. J.C. Consorciação da cana-de-açúcar com plantas alimentares: fatores que influenciam sua adoção. Piracicaba, 1989. 179p. Dissertação (Mestrado)-Escola Superior de Agricultura "Luiz de Queiroz", Unversidade de São Paulo.

ROMANACH, L.M.; CARON, D. Impactos da mecanização da colheita de cana sobre o emprego, a gestão ambiental e o meio ambiente (compact disc). In: CONGRESSO DA SOBER 37., Foz do Iguaçu, 1999. Anais. Foz do Iguaçu: SOBER, 1999.

RUTTAN, V. R. Research on the economics of technological change in american agriculture. Journal of Farm Economics, n.42, v. 4, p. 735-755, 1960. 
SERODIO, E. Analisando as políticas existentes e traçando perspectivas para o setor sucroalcooleiro. In: TENDÊNCIAS DE PREÇOS E QUESTÕES POLÍTICAS DETERMINANTES PARA O MERCADO DE AÇÚCAR E ÁLCOOL, São Paulo, 1999. Anais. São Paulo: International Business Communications, 1999. p.14-17

SILVA, G.M.A. Cana crua $x$ cana quiemada. In: SEMANA DA CANA-DEAÇÚCAR DE PIRACICABA 2., Piracicaba, 1997. Anais. Piracicaba: STAB, 1997. p.55-57.

SINCLAIR, F. A general classification of agroforestry practice. Agroforestry Systems, v.46, p.161-180, 1999.

SPAROVEK, G. Informações geográficas para a identificação de áreas com potencialidade para colheita de cana crua. In: SEMANA DA CANA-DEAÇÚCAR DE PIRACICABA 2., Piracicaba, 1997. Anais. Piracicaba: STAB, 1997. p.58-60.

SPAROVEK, G.; PEREIRA, J.C.; ALLEONI, L.R.F.; ROSSETTO, R. Aptidão das terras de Piracicaba (SP) para o corte mecanizado de cana-de-açúcar. Piracicaba. STAB, v.15, n.5, p.14-17, 1997.

SZMRECSÁNYI, T. O planejamento da agroindústria canavieira do Brasil (1930-1975). São Paulo: HUCITEC, 1979. 515p.

USINAS E DESTILARIAS DO OESTE PAULISTA. http://www.udop.com.br (18 mar. 2002).

UNIÃO DA AGROINDÚSTRIA CANAVIEIRA DE SÃO PAULO. Informação Unica, v. 2, n.23, p.4, ago, 1999. 
UNIÃO DA AGROINDÚSTRIA CANAVIEIRA DO ESTADO DE SÃO PAULO. Aspectos sociais, econômicos e tecnológicos da produção de açúcar e álcool no Estado de São Paulo: 2001/2002. São Paulo: UNICA, 2002. 28p.

VAZ DA SILVA, P.P. Sistemas agroflorestais para recuperação de matas ciliares em Piracicaba, SP. Piracicaba, 2002. 98p. Dissertação (Mestrado)Escola Superior de Agricultura "Luiz de Queiroz", Universidade de São Paulo.

VEIGA FILHO, A. O processo de transformação da lavoura canavieira paulista e evidências históricas da mecanização no período 1920-1950. Informações econômicas, v.32, n.3,.p.7-24, mar. 2002.

VEIGA FILHO, A.; SOUZA SANTOS, Z. A. P. Padrão tecnológico da cana-deaçúcar no Estado de São Paulo: evidências empíricas da evolução na cultura. Informações Econômicas, v.25, n.8, p.15-25, ago. 1995.

VEIGA FILHO, A.; SOUZA SANTOS, Z. A. P.; VEIGA, J. E. R.; OTANI, M. N.; YOSHII, R. J. Análise da mecanização do corte da cana-de-açúcar no Estado de São Paulo. Informações Econômicas, v.24, n.10, p.43-58, out. 1994. 


\section{APÊNDICES}


APÊNDICE 1. Respostas obtidas com a aplicação dos questionários:

Tabela 1. Porcentual médio de fornecedores de cana-de-açúcar segundo posse da terra.

\begin{tabular}{lccccc}
\hline \multirow{2}{*}{ Tipo de posse da terra } & $\begin{array}{c}\text { Rio das } \\
\text { Pedras } \\
\mathrm{n}=7\end{array}$ & $\begin{array}{c}\text { Charqueada } \\
\mathrm{n}=10\end{array}$ & $\begin{array}{c}\text { Iracemápolis } \\
\mathrm{n}=6\end{array}$ & $\begin{array}{c}\text { Ipeúna } \\
\mathrm{n}=2\end{array}$ & $\begin{array}{c}\text { Total } \\
\mathrm{n}=25\end{array}$ \\
\hline Própria & 57,14 & 0 & 50 & 100 & 51,79 \\
Própria e arrendada & 28,57 & 80 & 50 & 0 & 39,64 \\
Própria, arrendada e tercerizada. & 14,29 & 20 & 0 & 0 & 8,57 \\
\hline
\end{tabular}

Tabela 2. Percentual médio dos fornecedores de cana-de-açúcar com plantios novos.

\begin{tabular}{lccccc}
\hline Ano do plantio & $\begin{array}{c}\text { Rio das } \\
\text { Pedras } \\
\mathrm{n}=7\end{array}$ & $\begin{array}{c}\text { Charqueada } \\
\mathrm{n}=10\end{array}$ & $\begin{array}{c}\text { Iracemápolis } \\
\mathrm{n}=6\end{array}$ & $\begin{array}{c}\text { Ipeúna } \\
\mathrm{n}=2\end{array}$ & $\begin{array}{c}\text { Média } \\
\text { Total } \\
\mathrm{n}=25\end{array}$ \\
\hline Plantio em 2001 & 0 & 0 & 0 & 0 & 0 \\
Plantio em 2001 e em 2002 & 100 & 100 & 100 & 100 & 100 \\
\hline
\end{tabular}

Tabela 3. Percentual médio do destino da produção dos fornecedores entrevistados.

\begin{tabular}{lccccc}
\hline \multirow{2}{*}{ Destino } & Rio das & & & & Média \\
& Pedras & Charqueada & Iracemápolis & Ipeúna & Total \\
& $\mathrm{n}=7$ & $\mathrm{n}=10$ & $\mathrm{n}=6$ & $\mathrm{n}=2$ & $\mathrm{n}=25$ \\
\hline Uma Usina & 100 & 80 & 50 & 100 & 82,5 \\
Duas Usinas & 0 & 0 & 50 & 0 & 12,5 \\
Uma Usina e destilaria própria & 0 & 20 & 0 & 0 & 5 \\
\hline
\end{tabular}

Tabela 4. Percentual médio das perspectivas de produção de cana-de-açúcar dos fornecedores.

\begin{tabular}{lccccc}
\hline Produção & $\begin{array}{c}\text { Rio das } \\
\text { Pedras } \\
\mathrm{n}=7\end{array}$ & $\begin{array}{c}\text { Charqueada } \\
\mathrm{n}=10\end{array}$ & $\begin{array}{c}\text { Iracemápolis } \\
\mathrm{n}=6\end{array}$ & $\begin{array}{c}\text { Ipeúna } \\
\mathrm{n}=2\end{array}$ & $\begin{array}{c}\text { Média Total } \\
\mathrm{n}=25\end{array}$ \\
\hline Aumentará & 57,14 & 60 & 16,67 & 0 & 33,45 \\
Diminuirá & 0 & 0 & 0 & 0 & 0 \\
Manterá & 42,86 & 40 & 83,33 & 100 & 66,55 \\
\hline
\end{tabular}

Tabela 5. Percentual médio dos fatores que influenciam as perspectivas de produção.

\begin{tabular}{lccccc}
\hline Fatores & Rio das & & & & \\
Pedras & Charqueada & Iracemápolis & Ipeúna & Média Total \\
Principais & $\mathrm{n}=7$ & $\mathrm{n}=10$ & $\mathrm{n}=6$ & $\mathrm{n}=2$ & $\mathrm{n}=25$ \\
\hline 1. Preço & 14,28 & 0 & 0 & 0 & 3,57 \\
2. Usina & 0 & 0 & 0 & 0 & 0,00 \\
3. Área disponível & 42,86 & 90 & 66,67 & 100 & 74,88 \\
4. Outros & 42,86 & 10 & 33,33 & 0 & 21,55 \\
\hline
\end{tabular}




\begin{tabular}{|c|c|c|c|c|c|c|}
\hline Variedades & R. das Pedras & Charqueada & Iracemápolis & Ipeúna & & Total \\
\hline RB 72454 & 6 & 10 & 4 & 2 & & 22 \\
\hline SP 80-1842 & 3 & 6 & 5 & 0 & & 14 \\
\hline RB 835089 & 3 & 4 & 1 & 0 & & 8 \\
\hline SP 801816 & 4 & 0 & 3 & 0 & & 7 \\
\hline SP $80-3280$ & 2 & 0 & 4 & 0 & & 6 \\
\hline RB 855536 & 2 & 1 & 2 & 0 & & 5 \\
\hline RB 785148 & 2 & 1 & 1 & 0 & & 4 \\
\hline RB 855156 & 1 & 3 & 0 & 0 & & 4 \\
\hline Outras & 14 & 8 & 4 & 0 & & 26 \\
\hline SP 70-1143 & 1 & 0 & 0 & 0 & & 1 \\
\hline RB 855336 & 1 & 2 & 0 & 0 & & 3 \\
\hline RB 855451 & 1 & 0 & 0 & 0 & & 1 \\
\hline RB 855113 & 2 & 1 & 0 & 0 & & 3 \\
\hline RB 765418 & 1 & 0 & 0 & 0 & & 1 \\
\hline SP 70-1284 & 1 & 0 & 0 & 0 & & 1 \\
\hline RB 835054 & 2 & 1 & 0 & 0 & & 3 \\
\hline RB 865453 & 1 & 1 & 0 & 0 & & 2 \\
\hline RB 835486 & 1 & 0 & 0 & 0 & & 1 \\
\hline RB 857515 & 1 & 0 & 0 & 0 & & 1 \\
\hline RB 806043 & 1 & 0 & 2 & 0 & & 3 \\
\hline RB 855210 & 0 & 1 & 0 & 0 & & 1 \\
\hline RB 855556 & 0 & 2 & 0 & 0 & & 2 \\
\hline \multicolumn{7}{|c|}{ Tabela 7. Percentual médio da origem das mudas utilizadas pelos fornecedores de cana-de-açúcar entrevistados } \\
\hline \multicolumn{2}{|c|}{ Origem das mudas } & $\begin{array}{c}\text { Pedras } \\
n=7\end{array}$ & $\begin{array}{c}\text { Charqueada I } \\
n=10\end{array}$ & $\begin{array}{c}\text { Iracemápolis } \\
n=6\end{array}$ & $\begin{array}{c}\text { Ipeúna } \\
n=2\end{array}$ & $\begin{array}{l}\text { Total } \\
\mathrm{n}=25\end{array}$ \\
\hline \multicolumn{2}{|l|}{ Própria } & 14,29 & 10 & 0 & 0 & 6,07 \\
\hline \multicolumn{2}{|c|}{ Própria e da Usina } & 14,29 & 20 & 16,67 & 0 & 12,74 \\
\hline \multicolumn{2}{|c|}{ Usina } & 42,85 & 50 & 66,66 & 50 & 52,38 \\
\hline \multicolumn{2}{|c|}{ Usina e de outro fornecedor } & 14,28 & 0 & 0 & 0 & 3,57 \\
\hline \multicolumn{2}{|c|}{ Usina e AFOCAPI } & 0 & 10 & 0 & 0 & 2,50 \\
\hline \multicolumn{2}{|c|}{ Fornecedor e da AFOCAPI } & 14,29 & 0 & 0 & 50 & 16,07 \\
\hline \multicolumn{2}{|c|}{ Própria, usina e AFOCAPI } & 0 & 10 & 0 & 0 & 2,50 \\
\hline \multicolumn{2}{|c|}{ Própria, usina e fornecedor } & 0 & 0 & 16,67 & 0 & 4,17 \\
\hline \multicolumn{7}{|c|}{$\begin{array}{l}\text { Tabela 8. Percentual médio do método utilizado pelos fornecedores entrevistados para a renovação do canavial } \\
\text { Rio das }\end{array}$} \\
\hline \multicolumn{2}{|c|}{ Eliminação da soqueira } & $\begin{array}{c}\text { Pedras } \\
\mathrm{n}=7\end{array}$ & $\begin{array}{c}\text { Charqueada I } \\
n=10\end{array}$ & $\begin{array}{l}\text { Iracemápolis } \\
n=6\end{array}$ & $\begin{array}{l}\text { Ipeúna } \\
n=2\end{array}$ & $\begin{array}{l}\text { Total } \\
\mathrm{n}=25\end{array}$ \\
\hline \multirow{2}{*}{\multicolumn{2}{|c|}{$\begin{array}{l}\text { Arado } \\
\text { Grade e subsolador }\end{array}$}} & 28,58 & 0 & 0 & 0 & 7,15 \\
\hline & olador & 28,58 & 50 & 16,67 & 0 & 23,81 \\
\hline \multicolumn{2}{|c|}{ Herbicida, grade e subsolador } & 14,28 & 0 & 0 & 0 & 3,57 \\
\hline \multicolumn{2}{|c|}{ Arado e grade } & 14,28 & 10 & 0 & 50 & 18,57 \\
\hline \multicolumn{2}{|c|}{ Grade } & 0 & 0 & 66,66 & 50 & 29,17 \\
\hline \multicolumn{2}{|c|}{ Arado, grade e subsolador. } & 14,28 & 30 & 16,67 & 0 & 15,24 \\
\hline \multicolumn{2}{|c|}{ Arado, grade, herbicida e subsolador } & 0 & 10 & 0 & 0 & 2,50 \\
\hline
\end{tabular}


Tabela 9. Percentual médio de fornecedores segundo as formas de preparo do solo

\begin{tabular}{|c|c|c|c|c|c|}
\hline Preparo do solo & $\begin{array}{c}\text { Rio das } \\
\text { Pedras } \\
n=7\end{array}$ & $\begin{array}{c}\text { Charqueada } \\
n=10\end{array}$ & $\begin{array}{l}\text { Iracemápolis } \\
n=6\end{array}$ & $\begin{array}{l}\text { Ipeúna } \\
n=2\end{array}$ & $\begin{array}{c}\text { Média } \\
\text { Total } \\
n=25\end{array}$ \\
\hline Aração, nivelamento, sulcado, subsolagem e gradagem & 14,29 & 40 & 16,67 & 0 & 17,74 \\
\hline Nivelamento, sulcado, subsolagem e gradagem & 28,57 & 10 & 0 & 0 & 9,64 \\
\hline Aração, subsolado e gradagem & 14,28 & 0 & 0 & 0 & 3,57 \\
\hline Nivelamento e sulcado & 0 & 10 & 0 & 0 & 2,50 \\
\hline Aração e sulcado & 0 & 10 & 0 & 0 & 2,50 \\
\hline Sulcado, queima, subsolagem e gradagem & 0 & 10 & 0 & 0 & 2,50 \\
\hline Aração, nivelamento, sulcado e gradagem & 0 & 0 & 33,33 & 50 & 20,83 \\
\hline Aração, nivelamento, sulcado e subsolagem & 0 & 0 & 16,67 & 0 & 4,17 \\
\hline Sulcado e gradagem & 0 & 0 & 16,67 & 0 & 4,17 \\
\hline Queima & 0 & 0 & 0 & 0 & 0,00 \\
\hline Nivelamento, sulcado e gradagem & 0 & 10 & 0 & 50 & 15,00 \\
\hline Subsolagem e gradagem & 28,57 & 0 & 0 & 0 & 7,14 \\
\hline Aração, sulcado e gradagem & 14,29 & 0 & 0 & 0 & 3,57 \\
\hline Nivelamento, sulcado, subsolagem & 0 & 10 & 16,66 & 0 & 6,67 \\
\hline
\end{tabular}

Tabela 10. Percentual médio dos fornecedores que realizam análise de solo

\begin{tabular}{lccccc}
\hline \multirow{2}{*}{ Análise de solo } & Rio das Pedras & Charqueada & Iracemápolis & Ipeúna & $\begin{array}{c}\text { Média } \\
\end{array}$ \\
& $\mathrm{n}=7$ & $\mathrm{n}=10$ & $\mathrm{~T}=6$ & $\mathrm{n}=2$ & $\mathrm{n}=25$ \\
\hline Sim & 100 & 90 & 100 & 100 & 97,5 \\
Não & 0 & 10 & 0 & 0 & 2,5 \\
\hline
\end{tabular}

Tabela 11. Percentual médio dos fornecedores que realizam calagem do solo

\begin{tabular}{lccccc}
\hline \multirow{2}{*}{ Calagem } & Rio das Pedras & Charqueada & Iracemápolis & Ipeúna & Média \\
& $\mathrm{n}=7$ & $\mathrm{n}=10$ & $\mathrm{~T}=6$ & $\mathrm{n}=2$ & $\mathrm{n}=25$ \\
\hline Sim & 100 & 100 & 100 & 100 & 100 \\
Não & 0 & 0 & 0 & 0 & 0 \\
\hline
\end{tabular}

Tabela 12. Percentual médio de fornecedores de acordo com o tipo de adubação utilizada na cultura da cana-de-

\begin{tabular}{|c|c|c|c|c|c|}
\hline Adubação & $\begin{array}{c}\text { Rio das } \\
\text { Pedras } \\
n=7\end{array}$ & $\begin{array}{c}\text { Charqueada } \\
n=10\end{array}$ & $\begin{array}{c}\text { Iracemápolis } \\
n=6\end{array}$ & $\begin{array}{l}\text { Ipeúna } \\
\mathrm{n}=2\end{array}$ & $\begin{array}{c}\text { Média } \\
\text { Total } \\
\mathrm{n}=25\end{array}$ \\
\hline Orgánica & 0 & 0 & 0 & 0 & 0 \\
\hline Orgánica e mineral química & 42,86 & 10 & 0 & 0 & 13,21 \\
\hline Mineral natural & 0 & 0 & 0 & 0 & 0 \\
\hline Mineral química & 57,14 & 90 & 100 & 100 & 86,79 \\
\hline
\end{tabular}


Tabela 13. Quantidade de fornecedores para cada época de adubação da cana-de-açúcar

\begin{tabular}{lccccc}
\hline \multirow{2}{*}{ Época } & Rio das & & & & Média \\
& $\begin{array}{c}\text { Pedras } \\
\mathrm{n}=7\end{array}$ & $\begin{array}{c}\text { Charqueada } \\
\mathrm{n}=10\end{array}$ & $\begin{array}{c}\text { Iracemápolis } \\
\text { Ipeúna }\end{array}$ & $\begin{array}{c}\text { Total } \\
\mathrm{n}=2\end{array}$ & $\mathrm{n}=25$ \\
\hline Plantio & 0 & 0 & 0 & 0 & 0,00 \\
Plantio e cobertura & 0 & 0 & 0 & 0 & 0,00 \\
Plantio, cobertura e soqueira & 71,42 & 90 & 16,67 & 100 & 69,52 \\
Plantio e soqueira & 28,58 & 10 & 83,33 & 0 & 30,48 \\
Soqueira & 0 & 0 & 0 & 0 & 0,00 \\
\hline
\end{tabular}

Tabela 14. Percentual médio da origem dos adubos utilizados pelos fornecedores entrevistados

\begin{tabular}{lccccc}
\hline \multirow{2}{*}{ Origem } & Rio das & & & & Média \\
& $\begin{array}{c}\text { Pedras } \\
\mathrm{n}=7\end{array}$ & $\begin{array}{c}\text { Charqueada } \\
\mathrm{n}=10\end{array}$ & $\begin{array}{c}\text { Iracemápolis } \\
\text { Ipeúna }\end{array}$ & $\begin{array}{c}\text { Total } \\
\mathrm{n}=2\end{array}$ & $\mathrm{n}=25$ \\
\hline Industria & 0 & 90 & 16,67 & 0 & 26,67 \\
Usina & 0 & 0 & 0 & 0 & 0,00 \\
COPLANA & 85,71 & 0 & 50 & 100 & 58,93 \\
COPLANA e industria & 14,29 & 0 & 16,67 & 0 & 7,74 \\
Outros & 0 & 10 & 16,66 & 0 & 6,67 \\
\hline
\end{tabular}

Tabela 15. Percentual médio dos fornecedores de acordo com o tipo de plantio da cana

\begin{tabular}{lccccc}
\hline \multirow{2}{*}{ Plantio } & Rio das & & & & Média \\
& Pedras & Charqueada & Iracemápolis & Ipeúna & $\begin{array}{c}\text { Total } \\
n=7\end{array}$ \\
& $n=10$ & $n=6$ & $n=2$ & $n=25$ \\
\hline Manual (1,3m e 0,35-0,40m) & 100 & 100 & 100 & 100 & 100 \\
Semi-mecanizado & 0 & 0 & 0 & 0 & 0 \\
Mecanizado & 0 & 0 & 0 & 0 & 0 \\
\hline
\end{tabular}

Tabela 16. Percentual médio dos fornecedores que realizam algumas técnicas de manejo da cultura da cana

\begin{tabular}{lcccccc}
\hline \multirow{2}{*}{ Manejo } & $\begin{array}{c}\text { Rio das } \\
\text { Pedras } \\
\mathrm{n}=7\end{array}$ & $\begin{array}{c}\text { Charqueada } \\
\mathrm{n}=10\end{array}$ & $\begin{array}{c}\text { Iracemápolis } \\
\mathrm{n}=6\end{array}$ & $\begin{array}{c}\text { Ipeúna } \\
\mathrm{n}=2\end{array}$ & $\begin{array}{c}\text { Média } \\
\text { Total }\end{array}$ \\
& 71,42 & 50 & 66,66 & 0 & 47,02 \\
\hline Var. Resistentes e queima & 0 & 10 & 0 & 50 & 15,00 \\
Var. Resistentes & 28,58 & 30 & 16,67 & 50 & 31,31 \\
Var. Resistentes, queima e rotação & 0 & 10 & 0 & 0 & 2,50 \\
Adubos verdes, variedades e rotação & 0 & 0 & 0 & 0 & 0,00 \\
Plantio direto & 0 & 0 & 16,67 & 0 & 4,17 \\
Variedades, associação de culturas e queima & 0 & 0 & 0 & 0 & 0,00 \\
Outros & & & &
\end{tabular}


Tabela 17. Percentual médio dos fornecedores que realizam práticas de conservação do solo

\begin{tabular}{lccccc}
\hline \multirow{2}{*}{ Práticas } & $\begin{array}{c}\text { Rio das } \\
\text { Pedras } \\
\mathrm{n}=7\end{array}$ & $\begin{array}{c}\text { Charqueada } \\
\mathrm{n}=10\end{array}$ & $\begin{array}{l}\text { Iracemápolis } \\
\mathrm{n}=6\end{array}$ & $\begin{array}{c}\text { Ipeúna } \\
\mathrm{n}=2\end{array}$ & $\begin{array}{c}\text { Média } \\
\mathrm{n}=25\end{array}$ \\
\hline Curvas de nível & 14,29 & 0 & 0 & 0 & 3,57 \\
Proteção e terraceamento & 0 & 10 & 33,33 & 0 & 10,83 \\
Proteção de fontes de água & 14,29 & 0 & 0 & 0 & 3,57 \\
C. de nível e terraceamento & 14,29 & 10 & 16,67 & 50 & 22,74 \\
C. de nível, terraceam., cult. faixas e prot. & 0 & 10 & 0 & 0 & 2,50 \\
C. de nível, terraceamento e proteção & 42,84 & 40 & 50 & 50 & 45,71 \\
Proteção e culturas em faixas & 14,29 & 30 & 0 & 0 & 11,07 \\
\hline
\end{tabular}

Tabela 18. Percentual médio dos fornecedores de acordo com o critério utilizado para a colheita.

\begin{tabular}{|c|c|c|c|c|c|}
\hline Critérios & $\begin{array}{c}\text { Rio das } \\
\text { Pedras } \\
n=7\end{array}$ & $\begin{array}{c}\text { Charqueada } \\
n=10\end{array}$ & $\begin{array}{c}\text { Iracemápolis } \\
n=6\end{array}$ & $\begin{array}{c}\text { Ipeúna } \\
n=2\end{array}$ & $\begin{array}{c}\text { Média } \\
\text { Total } \\
\mathrm{n}=25 \\
\end{array}$ \\
\hline Análise na AFOCAPI & 14,29 & 20 & 33,32 & 100 & 41,90 \\
\hline AFOCAPI e análise na usina & 28,55 & 30 & 16,67 & 0 & 18,81 \\
\hline Entrada na usina & 14,29 & 20 & 16,67 & 0 & 12,74 \\
\hline Análise na usina & 14,29 & 0 & 16,67 & 0 & 7,74 \\
\hline AFOCAPI e idade da cana & 14,29 & 0 & 16,67 & 0 & 7,74 \\
\hline Idade da cana e entrada na usina & 14,29 & 30 & 0 & 0 & 11,07 \\
\hline
\end{tabular}

Tabela 19. Percentual médio dos fornecedores de acordo com o destino da palha da cana.

\begin{tabular}{lccccc} 
Destino da palha & $\begin{array}{c}\text { Rio das } \\
\text { Pedras } \\
\mathrm{n}=7\end{array}$ & $\begin{array}{c}\text { Charqueada } \\
\mathrm{n}=10\end{array}$ & $\begin{array}{c}\text { Iracemápolis } \\
\mathrm{n}=6\end{array}$ & $\begin{array}{c}\text { Ipeúna } \\
\mathrm{n}=2\end{array}$ & $\begin{array}{c}\text { Média } \\
\text { Total } \\
\mathrm{n}=25\end{array}$ \\
\hline Espalhada & 0 & 20 & 16,67 & 0 & 9,17 \\
Enleirada sem queima & 14,29 & 30 & 33,33 & 0 & 19,41 \\
Enleirada com queima & 71,42 & 40 & 50 & 100 & 65,36 \\
Queima & 14,29 & 10 & 0 & 0 & 6,07 \\
\hline
\end{tabular}

Tabela 20. Percentual médio dos fornecedores de acordo com o tipo de mão-de-obra empregada.

\begin{tabular}{lccccc}
\hline Mão-de-obra & Rio das & & & & \\
& $\begin{array}{c}\text { Pedras } \\
\mathrm{n}=7\end{array}$ & $\begin{array}{c}\text { Charqueada } \\
\mathrm{n}=10\end{array}$ & $\begin{array}{l}\text { Iracemápolis } \\
\mathrm{n}=6\end{array}$ & $\begin{array}{c}\text { Ipeúna } \\
\mathrm{n}=2\end{array}$ & $\begin{array}{c}\text { Total } \\
\mathrm{n}=25\end{array}$ \\
\hline Familiar & 0 & 0 & 0 & 0 & 0,00 \\
Familiar e permanente & 0 & 0 & 0 & 0 & 0,00 \\
Familiar, permanente e temporária & 71,42 & 50 & 50 & 50 & 55,36 \\
Familiar e temporária & 28,58 & 50 & 50 & 50 & 44,65 \\
\hline
\end{tabular}


Tabela 21. Freqüência dos fornecedores entrevistados segundo os principais problemas com a prática agronômica que dificultam a produção de cana-de-açúcar.

\begin{tabular}{|c|c|c|c|c|c|}
\hline Problemas agronômicos & $\begin{array}{c}\text { Rio das } \\
\text { Pedras } \\
n=7\end{array}$ & $\begin{array}{c}\text { Charqueada } \\
n=10\end{array}$ & $\begin{array}{c}\text { Iracemápolis } \\
n=6\end{array}$ & $\begin{array}{l}\text { Ipeúna } \\
\mathrm{n}=2\end{array}$ & $\begin{array}{c}\text { Média } \\
\text { Total } \\
\mathrm{n}=25\end{array}$ \\
\hline Falta de experiência com a cultura & 1 & 0 & 0 & 0 & 1 \\
\hline Dificuldade de obter insumos & 1 & 0 & 0 & 0 & 1 \\
\hline Falta de máquinas e equipamentos & 1 & 3 & 0 & 0 & 4 \\
\hline Falta de informações e conhecimentos técnicos & 2 & 2 & 1 & 0 & 5 \\
\hline Controle de pragas e doenças & 2 & 1 & 1 & 0 & 4 \\
\hline Controle de plantas daninhas & 2 & 3 & 0 & 1 & 6 \\
\hline Dificuldades na programação da produção & 1 & 1 & 0 & 0 & 2 \\
\hline Outros & 2 & 2 & 2 & 0 & 6 \\
\hline Nenhum & 1 & 1 & 0 & 1 & 3 \\
\hline
\end{tabular}

Tabela 22. Freqüência dos fornecedores entrevistados segundo os aspectos técnicos mais importantes para serem resolvidos pela pesquisa em cana-de-açúcar

\begin{tabular}{lccccc}
\hline Problemas para a pesquisa em cana & $\begin{array}{c}\text { Rio das } \\
\text { Pedras } \\
\mathrm{n}=7\end{array}$ & $\begin{array}{c}\text { Charqueada } \\
\mathrm{n}=10\end{array}$ & $\begin{array}{c}\text { Iracemápolis } \\
\mathrm{n}=6\end{array}$ & $\begin{array}{c}\text { Meúna } \\
\mathrm{n}=2\end{array}$ & $\begin{array}{c}\text { Total } \\
\mathrm{n}=25\end{array}$ \\
\hline Estudo de variedades adaptadas & 4 & 7 & 3 & 1 & 15 \\
Controle de pragas e doenças & 2 & 0 & 1 & 0 & 3 \\
Controle de plantas daninhas & 3 & 2 & 0 & 0 & 5 \\
Desenvolvimento de máquinas e equipamentos & 2 & 1 & 3 & 0 & 6 \\
Manejo da matéria-orgânica e fertilidade do solo & 1 & 4 & 1 & 0 & 6 \\
Métodos eficientes para planejar a colheita & 2 & 1 & 0 & 0 & 3 \\
Adubos verdes & 0 & 0 & 0 & 0 & 0 \\
Outros & 1 & 2 & 1 & 1 & 5 \\
\hline
\end{tabular}

Tabela 23. Percentual médio dos fornecedores segundo a diversificação da produção

\begin{tabular}{lccccc}
\hline $\begin{array}{l}\text { Uso da terra para na } \\
\text { produção total }\end{array}$ & $\begin{array}{c}\text { Rio das } \\
\text { Pedras } \\
\mathrm{n}=7\end{array}$ & $\begin{array}{c}\text { Charqueada } \\
\mathrm{n}=10\end{array}$ & $\begin{array}{c}\text { Iracemápolis } \\
\mathrm{n}=6\end{array}$ & $\begin{array}{c}\text { Meúna } \\
\mathrm{n}=2\end{array}$ & $\begin{array}{c}\text { Média } \\
\text { Total } \\
\mathrm{n}=25\end{array}$ \\
\hline Milho & 1 & 4 & 4 & 2 & 11 \\
Soja & 1 & 0 & 0 & 0 & 1 \\
Feijão & 0 & 0 & 0 & 0 & 0 \\
Pastagens & 6 & 8 & 6 & 2 & 22 \\
Laranja & 1 & 0 & 1 & 0 & 2 \\
Bovinos & 7 & 8 & 5 & 2 & 22 \\
Aves & 4 & 8 & 5 & 0 & 17 \\
Suínos & 1 & 3 & 2 & 0 & 6 \\
Preservação Permanente & 1 & 5 & 2 & 1 & 9 \\
Mata ciliar & 5 & 3 & 3 & 1 & 12 \\
Nascentes & 0 & 1 & 0 & 0 & 1 \\
Reserva legal & 0 & 2 & 1 & 0 & 3 \\
Reflorestamento & 1 & 0 & 3 & 1 & 5 \\
\hline
\end{tabular}


Tabela 24. Percentual médio dos fornecedores que possuem área com declividade acima de $12 \%$.

\begin{tabular}{lccccc}
\hline $\begin{array}{l}\text { Declividade na área com cana-de- } \\
\text { açúcar }\end{array}$ & $\begin{array}{c}\text { Rio das } \\
\text { Pedras } \\
\mathrm{n}=7\end{array}$ & $\begin{array}{c}\text { Charqueada } \\
\mathrm{n}=10\end{array}$ & $\begin{array}{c}\text { Iracemápolis } \\
\mathrm{n}=6\end{array}$ & $\begin{array}{c}\text { Ipeúna } \\
\mathrm{n}=2\end{array}$ & $\begin{array}{c}\text { Média } \\
\text { Total } \\
\mathrm{n}=25\end{array}$ \\
\hline $\begin{array}{l}\text { Com problemas para a colheita } \\
\text { mecânica }\end{array}$ & 57,14 & 100 & 100 & 0 & 64,29 \\
$\begin{array}{l}\text { Sem problemas para a colheita } \\
\text { mecânica }\end{array}$ & 42,86 & 0 & 0 & 100 & 35,72 \\
\hline
\end{tabular}

Tabela 25. Percentual médio da utilização da cana para outras atividades.

\begin{tabular}{|c|c|c|c|c|c|}
\hline $\begin{array}{l}\text { Utilizam a cana para as seguintes } \\
\text { atividades }\end{array}$ & $\begin{array}{c}\text { Rio das } \\
\text { Pedras } \\
n=7\end{array}$ & $\begin{array}{c}\text { Charqueada } \\
n=10\end{array}$ & $\begin{array}{l}\text { Iracemápolis } \\
n=6\end{array}$ & $\begin{array}{l}\text { Ipeúna } \\
\mathrm{n}=2\end{array}$ & $\begin{array}{c}\text { Média } \\
\text { Total } \\
n=25\end{array}$ \\
\hline Ponta da cana para gado & 57,14 & 10 & 83,33 & 50 & 50,12 \\
\hline Esterco para adubação & 0 & 10 & 16,66 & 50 & 19,17 \\
\hline Nenhuma & 42,85 & 70 & 0 & 0 & 28,21 \\
\hline Outros & 0 & 10 & 0 & 0 & 2,50 \\
\hline
\end{tabular}

Tabela 26. Indicadores da importância da atividade canavieira para os fornecedores entrevistados.

\begin{tabular}{|c|c|c|c|c|c|}
\hline $\begin{array}{l}\text { Indicadores da influência da cana na } \\
\text { renda }\end{array}$ & $\begin{array}{c}\text { Rio das } \\
\text { Pedras } \\
n=7\end{array}$ & $\begin{array}{l}\text { Charqueada } \\
n=10\end{array}$ & $\begin{array}{l}\text { Iracemápolis } \\
n=6\end{array}$ & $\begin{array}{l}\text { Ipeúna } \\
\mathrm{n}=2\end{array}$ & $\begin{array}{c}\text { Média } \\
\text { Total } \\
\mathrm{n}=25\end{array}$ \\
\hline Acima de 20 anos como fornecedor & 7 & 10 & 6 & 1 & 24 \\
\hline Atividade anterior & 4 & 9 & 3 & 2 & 18 \\
\hline Pretende continuar plantando cana & 7 & 10 & 6 & 2 & 25 \\
\hline
\end{tabular}

Tabela 27. Outras atividades de renda adicionais dos fornecedores entrevistados.

\begin{tabular}{lccccc}
\hline $\begin{array}{l}\text { Atividades de renda além da } \\
\text { cana-de-açúcar }\end{array}$ & $\begin{array}{c}\text { Rio das } \\
\text { Pedras } \\
\mathrm{n}=7\end{array}$ & $\begin{array}{c}\text { Charqueada } \\
\mathrm{n}=10\end{array}$ & $\begin{array}{c}\text { Iracemápolis } \\
\mathrm{n}=6\end{array}$ & $\begin{array}{c}\text { Mpeúna } \\
\mathrm{n}=2\end{array}$ & $\begin{array}{c}\text { Média } \\
\text { Total } \\
\mathrm{n}=25\end{array}$ \\
\hline Serviços a terceiros & 3 & 6 & 1 & 0 & 10 \\
Venda de animais & 7 & 2 & 0 & 2 & 11 \\
Turismo rural & 0 & 1 & 0 & 1 & 2 \\
Destilaria & 1 & 2 & 0 & 0 & 3 \\
Venda de mudas cítricas & 0 & 0 & 1 & 0 & 1 \\
\hline
\end{tabular}


Tabela 28. Freqüência das respostas emitidas em relação à intenção de investimento do entrevistado

\begin{tabular}{lccccc}
\hline $\begin{array}{l}\text { Atividades nas quais investiria } \\
\text { atualmente }\end{array}$ & $\begin{array}{c}\text { Rio das } \\
\text { Pedras } \\
\mathrm{n}=7\end{array}$ & $\begin{array}{c}\text { Charqueada } \\
\mathrm{n}=10\end{array}$ & $\begin{array}{c}\text { Iracemápolis } \\
\mathrm{n}=6\end{array}$ & $\begin{array}{c}\text { Ipeúna } \\
\mathrm{n}=2\end{array}$ & $\begin{array}{c}\text { Média } \\
\text { Total } \\
\mathrm{n}=25\end{array}$ \\
\hline Ampliar a produção de cana-de-açúcar & 3 & 1 & 0 & 0 & 4 \\
Renovação de variedades & 1 & 1 & 0 & 0 & 2 \\
Plantio de outras culturas & 1 & 3 & 2 & 1 & 7 \\
Aquisição de terras para a expansão da cana & 0 & 8 & 1 & 1 & 10 \\
Moradia (ampliação, melhoria, etc.) & 4 & 1 & 0 & 0 & 5 \\
Aquisição de bens domésticos & 1 & 0 & 0 & 0 & 1 \\
Aquisição de veículos & 0 & 0 & 1 & 0 & 1 \\
Compra de máquinas e implementos & 3 & 2 & 1 & 0 & 6 \\
Mudaria para a cidade & 0 & 0 & 0 & 0 & 0 \\
Outros & 2 & 6 & 3 & 1 & 12 \\
\hline
\end{tabular}

Tabela 29. Indicadores do nível de conhecimento de SAF dos fornecedores entrevistados.

\begin{tabular}{lccccc}
\hline Indicadores & $\begin{array}{c}\text { Rio das } \\
\text { Pedras } \\
\mathrm{n}=7\end{array}$ & $\begin{array}{c}\text { Charqueada } \\
\mathrm{n}=10\end{array}$ & $\begin{array}{c}\text { Iracemápolis } \\
\mathrm{n}=6\end{array}$ & $\begin{array}{c}\text { Ipeúna } \\
\mathrm{n}=2\end{array}$ & $\begin{array}{c}\text { Média } \\
\text { Total }\end{array}$ \\
& 0 & 1 & 2 & 0 & 3 \\
\hline Conhece o SAF & 0 & 0 & 0 & 0 & 0 \\
Já visitou algum & 0 & 1 & 1 & 0 & 2 \\
Conhece resultados de pesquisas & 0 & 1 & 2 & 0 & 3 \\
SAF-CANA é sustentável & 3 & 6 & 2 & 2 & 15 \\
Não sabe & 1 & 0 & 1 & 0 & 2 \\
Transformaria em SAF-CANA? & 1 & 3 & 2 & 1 & 9 \\
Dependeria dos resultados & & & &
\end{tabular}

Tabela 30. Indicadores tecnológicos dos entraves para a adoção de SAF identificados pelos fornecedores

\begin{tabular}{lccccc}
\hline Problemas críticos para a adoção de & $\begin{array}{c}\text { Rio das } \\
\text { Pedras } \\
\mathrm{n}=7\end{array}$ & $\begin{array}{c}\text { Charqueada } \\
\mathrm{n}=10\end{array}$ & $\begin{array}{c}\text { Iracemápolis } \\
\mathrm{n}=6\end{array}$ & $\begin{array}{c}\text { Ipeúna } \\
\mathrm{n}=2\end{array}$ & $\begin{array}{c}\text { Média } \\
\text { Total } \\
\mathrm{n}=25\end{array}$ \\
SAF-CANA & 0 & 1 & 0 & 0 & 1 \\
\hline Falta de crédito agrícola específico & 0 & 4 & 0 & 0 & 4 \\
Falta de resultados de pesquisa & 0 & 3 & 2 & 0 & 5 \\
Dificuldade para obtenção de insumos & 2 & 3 & 2 & 0 & 7 \\
Falta de experiência & 2 & 3 & 4 & 0 & 9 \\
Comercialização da produção & 2 & 4 & 3 & 0 & 9 \\
Obtenção de informações e assistência técnica & 0 & 6 & 1 & 0 & 7 \\
Falta de mão-de-obra especializada & 0 & 2 & 4 & 0 & 2 \\
Outros & 3 & 0 & 2 & 2 & 7 \\
Não sabe & 0 & 1 & 0 & 0 & 1 \\
Fisiológicos & 0 & 1 & 0 & 0 & 1 \\
Erosão & 0 & 0 & 1 & 0 & 1 \\
Roubo dos produtos & & & & & \\
\hline
\end{tabular}


Tabela 31. Fatores que fazem o SAF-CANA de grande potencial de extensão.

\begin{tabular}{lccccc}
\hline Facilidade para extensão devido a: & $\begin{array}{c}\text { Rio das } \\
\text { Pedras } \\
\mathrm{n}=7\end{array}$ & $\begin{array}{c}\text { Charqueada } \\
\mathrm{n}=10\end{array}$ & $\begin{array}{c}\text { Iracemápolis } \\
\mathrm{n}=6\end{array}$ & $\begin{array}{c}\text { Mé́na } \\
\mathrm{n}=2\end{array}$ & $\begin{array}{c}\text { Total } \\
\mathrm{n}=25\end{array}$ \\
\hline Harmonia com a questão ambiental & 1 & 0 & 0 & 0 & 0 \\
Melhoria da qualidade de vida & 1 & 0 & 1 & 0 & 1 \\
Redução do uso de agrotóxicos e energia & 1 & 0 & 1 & 0 & 2 \\
Conservação dos recursos naturais & 1 & 0 & 0 & 0 & 2 \\
Melhores preços & 0 & 0 & 0 & 0 & 1 \\
Grande demanda atual & 0 & 0 & 0 & 0 & 0 \\
Fortalece a agricultura familiar & 1 & 1 & 1 & 0 & 0 \\
Fixação da população na área rural & 0 & 1 & 0 & 0 & 3 \\
Melhor aproveitamento da m. de obra & 1 & 0 & 0 & 0 & 1 \\
Certificação de alimentos & 0 & 0 & 2 & 0 & 1 \\
Outros & 4 & 6 & 1 & 2 & 2 \\
Não sabe & 0 & 0 & 1 & 0 & 14 \\
Produção & 0 & 2 & 1 & 0 & 2 \\
Aproveitar melhor a área & 0 & 0 & 1 & 0 & 4 \\
Garantia para venda & 0 & 0 & 0 & 0 & 1 \\
\hline
\end{tabular}

Tabela 32. Indicadores relacionados com o fornecedor para a adoção de SAF-CANA.

\begin{tabular}{lccccc}
\hline $\begin{array}{l}\text { Fatores que influenciariam } \\
\text { sua decisão }\end{array}$ & $\begin{array}{c}\text { Rio das } \\
\text { Pedras } \\
\mathrm{n}=7\end{array}$ & $\begin{array}{c}\text { Charqueada } \\
\mathrm{n}=10\end{array}$ & $\begin{array}{c}\text { Iracemápolis } \\
\mathrm{n}=6\end{array}$ & $\begin{array}{c}\text { Ipeúna } \\
\mathrm{n}=2\end{array}$ & $\begin{array}{c}\text { Média Total } \\
\mathrm{n}=25\end{array}$ \\
\hline Saúde pessoal e da família & 0 & 0 & 1 & 0 & 1 \\
Saúde do consumidor & 0 & 0 & 1 & 0 & 1 \\
Saúde da comunidade & 1 & 0 & 1 & 0 & 2 \\
Convicção ideológica & 0 & 0 & 1 & 0 & 1 \\
Razões econômicas & 0 & 2 & 2 & 1 & 5 \\
Política atual & 1 & 3 & 0 & 0 & 4 \\
Conservação de R. naturais & 1 & 2 & 2 & 1 & 6 \\
Melhorar a produtividade & 0 & 1 & 1 & 0 & 2 \\
Outras & 0 & 2 & 0 & 0 & 2 \\
Não sabe & 4 & 1 & 1 & 1 & 7 \\
Adaptável à propriedade & 1 & 0 & 0 & 0 & 1 \\
\hline
\end{tabular}


Tabela 33. Indicadores relacionados com a difusão de novas tecnologias para o fornecedor

\begin{tabular}{lccccc}
\hline Melhores médios de divulgar & $\begin{array}{l}\text { Rio das } \\
\text { Pedras } \\
\mathrm{n}=7\end{array}$ & $\begin{array}{c}\text { Charqueada } \\
\mathrm{n}=10\end{array}$ & $\begin{array}{l}\text { Iracemápolis } \\
\mathrm{n}=6\end{array}$ & $\begin{array}{c}\text { Ipeúna } \\
\mathrm{n}=2\end{array}$ & $\begin{array}{c}\text { Média } \\
\text { Total } \\
\mathrm{n}=25\end{array}$ \\
\hline Rádio & 0 & 1 & 0 & 0 & 1 \\
Jornal & 0 & 2 & 1 & 1 & 4 \\
Televisão & 1 & 4 & 4 & 2 & 11 \\
outros fornecedores & 0 & 3 & 0 & 0 & 4 \\
AFOCAPI & 6 & 5 & 4 & 2 & 17 \\
Prefeitura & 0 & 2 & 0 & 0 & 2 \\
CATI & 0 & 1 & 1 & 0 & 2 \\
consultorias & 0 & 0 & 0 & 0 & 0 \\
Mercado & 0 & 0 & 0 & 0 & 0 \\
SEMA/PMP & 1 & 0 & 0 & 0 & 1 \\
DRN-SM & 0 & 0 & 0 & 0 & 0 \\
Video & 0 & 0 & 0 & 0 & 0 \\
cursos/palestras & 2 & 3 & 2 & 2 & 9 \\
Internet & 0 & 5 & 0 & 0 & 5 \\
Usina & 2 & 0 & 6 & 0 & 8 \\
Livros & 0 & 1 & 0 & 0 & 1 \\
Revistas & 0 & 0 & 1 & 0 & 1 \\
\hline
\end{tabular}

Tabela 34. Indicadores tecnológicos principais para divulgar alternativas de produção.

\begin{tabular}{|c|c|c|c|c|c|}
\hline Temas de alternativas de produção & $\begin{array}{c}\text { Rio das } \\
\text { Pedras } \\
n=7\end{array}$ & $\begin{array}{c}\text { Charqueada } \\
n=10\end{array}$ & $\begin{array}{l}\text { Iracemápolis } \\
n=6\end{array}$ & $\begin{array}{l}\text { Ipeúna } \\
\mathrm{n}=2\end{array}$ & $\begin{array}{c}\text { Média } \\
\text { Total } \\
n=25\end{array}$ \\
\hline $\begin{array}{l}\text { Técnicas de produção (variedades, cont. de } \\
\text { p.d.) }\end{array}$ & 3 & 4 & 5 & 1 & 13 \\
\hline $\begin{array}{l}\text { Econômicos (comercialização, custos, } \\
\text { preços) }\end{array}$ & 3 & 8 & 2 & 1 & 14 \\
\hline Sociais e culturais (conscientização) & 0 & 2 & 1 & 0 & 3 \\
\hline $\begin{array}{l}\text { Ambientais (conservação dos rec. Nat.) } \\
\text { Institucionais (créditos, políticas de }\end{array}$ & 2 & 2 & 3 & 0 & 7 \\
\hline incentivos) & 2 & 3 & 1 & 0 & 6 \\
\hline Outros & 1 & 1 & 0 & 0 & 2 \\
\hline Não sabe & 0 & 0 & 0 & 0 & 0 \\
\hline
\end{tabular}

Tabela 35. Indicadores do complexo agro-industrial que afetam à produção de cana-de-açúcar.

\begin{tabular}{lccccc}
\hline $\begin{array}{l}\text { A industria seria prejudicada com a } \\
\text { redução da área plantada }\end{array}$ & $\begin{array}{c}\text { Rio das } \\
\text { Pedras } \\
\mathrm{n}=7\end{array}$ & $\begin{array}{c}\text { Charqueada } \\
\mathrm{n}=10\end{array}$ & $\begin{array}{c}\text { Iracemápolis } \\
\mathrm{n}=6\end{array}$ & $\begin{array}{c}\text { Ipeúna } \\
\mathrm{n}=2\end{array}$ & $\begin{array}{c}\text { Média } \\
\text { Total } \\
\mathrm{n}=25\end{array}$ \\
\hline Sim & 5 & 5 & 6 & 0 & 16 \\
Não & 2 & 5 & 0 & 2 & 9 \\
Área pequena & 1 & 3 & 0 & 2 & 6 \\
Suficiente terra & 0 & 1 & 0 & 0 & 1 \\
Pouca produção & 0 & 1 & 1 & 0 & 2 \\
Usina incentiva fornecedores & 0 & 3 & 2 & 0 & 5 \\
Muita área & 0 & 1 & 0 & 0 & 1 \\
Restrições exigidas pelo aeroporto & 0 & 0 & 1 & 0 & 1 \\
\hline
\end{tabular}




\section{APÊNDICE 2. QUESTIONÁRIO}

SISTEMA DE PRODUÇÃO DE CANA-DE-AÇÚCAR

\begin{tabular}{|c|c|c|c|c|c|c|}
\hline DESCRICCÃO & \multicolumn{3}{|c|}{ ÁREA DE PRODUÇÃO (há) } & PRODUCCÃO & ATR & VALOR \\
\hline Cana-de-açúcar & PRÓPRIA & ARRENDADA & PARCERIA & toneladas & t/há & $\mathrm{R} \$ / \mathrm{t}$ \\
\hline \multicolumn{7}{|l|}{ TOTAL } \\
\hline \multicolumn{7}{|l|}{ PLANTA 2001} \\
\hline \multicolumn{7}{|l|}{ SOCAS } \\
\hline \multicolumn{7}{|l|}{ PLANTA 2002} \\
\hline \multicolumn{7}{|l|}{ CANA SAFRA 2001} \\
\hline \multicolumn{7}{|c|}{ USINAS ONDE ENTREGOU } \\
\hline \multicolumn{7}{|l|}{ PREVISÃO 2002} \\
\hline \multirow{2}{*}{\multicolumn{2}{|c|}{$\begin{array}{l}\text { PRODUÇÃO IRÁ } \\
\text { INFLUENCIADA POR }\end{array}$}} & \multicolumn{5}{|c|}{ 1.AUMENTAR 2.DIMINUIR 3. MANTER 4. NÃO SABE } \\
\hline & & 1.PREÇO 2.PE & O DA USINA & ÁREA DISPON & EL $4 . C$ & TROS \\
\hline
\end{tabular}

\begin{tabular}{|l|l|l|}
\hline VARIEDADES & ÁREA (há) & $\%$ \\
\hline & & \\
\hline & & \\
\hline & & \\
\hline & & \\
\hline & & \\
\hline & & \\
\hline & & \\
\hline
\end{tabular}

MUDAS

ELIMINA SOCA

PREP. SOLO

ANÁLISE DE SOLO

CALAGEM

ADUBAÇÃO
1.PRÓPRIA 2.USINA 3.VIZINHO 4.AFOCAPI

1.ARADO 2.GRADE 3.ENX. ROTATIVA 4.HERBICIDA 5.OUTROS

1.ARAÇÃO 2.NIVELAMENTO 3.SULCADOR 4.QUEIMA 5. SUBSOLAGEM 6.GRADAGEM 7.OUTRO

1.SIM 2.NÃO TIPO DE SOLO

1.SIM 2.NÃO

1.ORGÂNICA 2.MINERAL NATURAL 3. MINERAL QUÍMICA

\begin{tabular}{|l|l|l|l|}
\hline \multicolumn{1}{|c|}{ ADUBAÇÃO } & ÉPOCA & DOSAGEM & MÉTODO \\
\hline PLANTIO & & & \\
\hline COBERTURA & & & \\
\hline SOCA & & & \\
\hline
\end{tabular}


ADUBOS

PLANTIO

1.INDUSTRIA DE ADUBOS 2. USINA 3. COPLANA 4.OUTROS

1.MANUAL 2.SEMI-MECÁNIZADO 3.MECANIZADO

ÉPOCA

ESPAÇAMENTO

PROFUNDIDADE DO SULCO

MANEJO

1.VAR.RESISTENTES 2.ROTAÇÃO 3.CULTURAS ENTRE LINHAS

4.PLANTIO DIRETO 5.QUEIMA 6.OUTROS

CONSERVAÇÃO DO SOLO

1.CURVAS DE NÍVEL 2.CULTIVO MÍNIMO 3.PROTEÇÃO DE FONTES D'ÁGUA

4.TERRACEAMENTO 5.CULTURAS EM FAIXAS 6.OUTRAS

CRITÉRIOS PARA O CORTE

1.ANÁLISE NA AFOCAPI 2.IDADE DA CANA 3.ENTRADA NA USINA

4.OUTRO

DESTINO DA PALHA

1.ESPALHADA 2.ENLEIRADA S/QUEIMA 3. ENLEIRADA PARA QUEIMA

4.QUEIMA

MÃO-DE-OBRA

\begin{tabular}{|c|c|c|c|c|c|}
\hline FAMILIAR & M/F & FUNÇÃO & hs/dia/semana & IDADE & \\
\hline & & 1. TECNICO & & & \\
\hline & & 2.OP.MAQ. & & & \\
\hline & & 3. BRAÇAL & & & \\
\hline & & & & & \\
\hline & MERMANENTE & FUNÇÀO & hs/dia/semana & IDADE & TEMPO DE SERVIÇO \\
\hline & & 1. TECNICO & & & \\
\hline & & 2. OP.MAQ. & & & \\
\hline & & 3. BRAÇAL & & & \\
\hline TEMPORARIA & M/F & FUNÇÀO & hs/dia/semana & IDADE & ÉPOCA \\
\hline & & $1 . T E C N I C O$ & & & \\
\hline & & 2. OP.MAQ. & & & \\
\hline & & 3. BRAÇAL & & & \\
\hline
\end{tabular}

ASSINALE OS PRINCIPAIS PROBLEMAS RELACIONADOS COM A PRÁTICA AGRONÔMICA QUE DIFICULTAM A PRODUÇÃO DE CANA-DE-AÇÚCAR

FALTA DE EXPERIÊNCIA COM A CULTURA

DIFICULDADE DE OBTER INSUMOS

FALTA DE MÁQUINAS E EQUIPAMENTOS

FALTA DE INFORMAÇÕES E CONHECIMENTOS TÉCNICOS

CONTROLE DE PRAGAS E DOENÇAS

CONTROLE DE PLANTAS DANINHAS

DIFICULDADE EM RELAÇÃO À PROGRAMAÇÃO DE PRODUÇÃO 
OUTROS

CITE 3 ASPECTOS TÉCNICOS MAIS IMPORTANTES PARA SEREM RESOLVIDOS PELA PESQUISA EM CANA-DE-AÇÚCAR

ESTUDO DE VARIEDADES ADAPTADAS

CONTROLE DE PRAGAS E DOENÇAS

CONTROLE DE PLANTAS DANINHAS

DESENVOLVIMENTO DE MÁQUINAS E EQUIPAMENTOS

MANEJO DA MATÉRIA-ORGÂNICA E FERTILIDADE DO SOLO

MÉTODOS EFICIENTES PARA PLANEJAR A COLHEITA

ADUBOS VERDES

OUTROS

SISTEMA DE USO DA TERRA

há

PRÓPRIA

ARRENDADA

OUTROS

TOTAL

OCUPAÇÃO DO SOLO

\begin{tabular}{|c|c|c|}
\hline \multicolumn{2}{|l|}{ DESCRIÇÃO } & ÁREA (há) \\
\hline \multicolumn{3}{|l|}{ TOTAL } \\
\hline \multirow[t]{5}{*}{ AGRÍCOLA ANUAL } & LAVOURAS & \\
\hline & FEIJÃO & \\
\hline & ARROZ & \\
\hline & MILHO & \\
\hline & OUTROS & \\
\hline \multicolumn{3}{|c|}{ AGRÍCOLA SEMI-PERENE } \\
\hline \multicolumn{3}{|l|}{ AGRÍCOLA PERENE } \\
\hline \multicolumn{3}{|l|}{ LARANJA } \\
\hline \multicolumn{3}{|l|}{ OUTROS } \\
\hline \multicolumn{3}{|l|}{ PECUÁRIA } \\
\hline \multicolumn{3}{|l|}{ BOVINOS } \\
\hline \multicolumn{3}{|l|}{ AVES } \\
\hline \multicolumn{3}{|l|}{ SUINOS } \\
\hline \multicolumn{3}{|l|}{ OUTROS } \\
\hline \multicolumn{3}{|c|}{ POUSIO _ _ n } \\
\hline $\begin{array}{r}\text { PRESERVAÇÃO PEF } \\
\text { mc: mata }\end{array}$ & $\begin{array}{l}\text { RMANENTE } \\
\text { illiar }\end{array}$ & \\
\hline
\end{tabular}

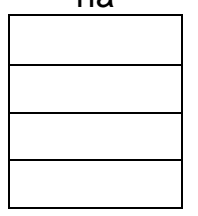

DESCRIÇÃO

TOTAL

AGRÍCOLA ANUAL LAVOURAS

FEIJÃO

ARROZ

MILHO

OUTROS

AGRÍCOLA SEMI-PERENE

(n)


$\mathrm{n}$ : nascentes

rl: reserva legal

REFLORESTAMENTO

INFRAESTRUTURA (benfeitorias, estradas, carreadores)

NÃO AGRÍCOLA (aguadas, improdutivas)

TOTAL

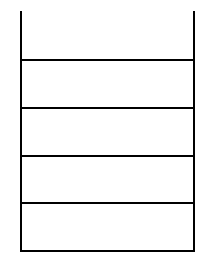

ÁREA QUE NÃO PODE COLHER COM MÁQUINA (DECLIVIDADE >12\%) INTEGRAÇÃO DE ATIVIDADES

AGRICULTURA / PECUÁRIA / FLORESTA / OUTROS

UTILIDADE DAS ATIVIDADES EM OUTRAS

1.PONTA DA CANA PARA GADO 2. ESTERCO PARA ADUBAÇÃO DA CANA 3. OUTROS

OUTRAS ATIVIDADES

\begin{tabular}{l|l|l|}
\cline { 3 - 3 } TEMPO COMO PLANTADOR DE CANA & ANOS \\
ATIVIDADE ANTERIOR & 1. NÃO 2. SIM & \\
\hline
\end{tabular}

POR QUE MUDOU PARA A PRODUÇÃO DE CANA?

PRETENDE CONTINUAR PLANTANDO CANA SEMPRE?

SIM NÃO POR QUE?

QUANTAS PESSOAS MORAM NA PROPRIEDADE?

QUANTAS PESSOAS MORAM FORA DA PROPRIEDADE MAS TRABALHAM NELA?

QUANTAS DESTAS PESSOAS TRABALHAM NO FUNDO AGRÍCOLA?

QUANTAS DESTAS TRABALHAM EM OUTRA PROPRIEDADE RURAL?

QUANTAS DESTAS TRABALHAM EM ATIVIDADES NÃO RURAIS?

1. PROFISSIONAIS 2. COMERCIANTES 3. OUTROS

OUTRAS ATIVIDADES DE RENDA

SERVIÇOS A TERCEIROS? QUAIS

VENDA DE ANIMAIS

TURISMO RURAL

DEPENDÊNCIA DA PRODUÇÃO DE CANA-DE-AÇÚCAR

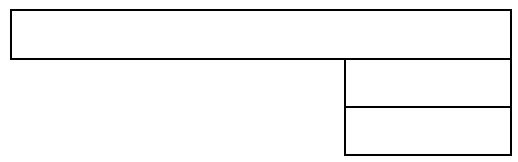

QUAL ATIVIDADE PROPORCIONA MAIOR RENDA?

AGRÍCOLA

PECUÁRIA

COMERCIAL

PROFISSIONAL

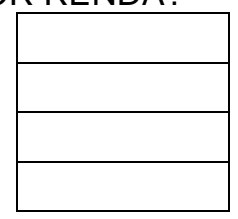

SE TIVESSE RECURSOS HOJE EM QUE INVESTIRIA

AMPLIAR A PRODUÇÃO DE CANA-DE-AÇÚCAR NA PROPRIEDADE ATUAL RENOVAÇÃO DE VARIEDADES

PLANTIO DE OUTRAS CULTURAS 
AQUISIÇÃO DE TERRAS PARA A EXPANSÃO DA CANA-DE-AÇÚCAR MORADIA (AMPLIAÇÃO, MELHORIA, REFORMAS) AQUISIÇÃO DE BENS DOMÉSTICOS AQUISIÇÃO DE VEÍCULOS COMPRA DE MAQUINÁRIAS E IMPLEMENTOS MUDARIA PARA A CIDADE OUTROS

LEGISLAÇÃO AMBIENTAL TERCERIZA A COLHEITA?

NÃO SIM PARA QUEM? CUSTO

COLHEITA MECANIZADA

COLHEITA DE CANA CRUA REALIZA QUEIMA PREVIA AO CORTE? ALGUMA VEZ RECEBEU MULTA POR QUEIMA?

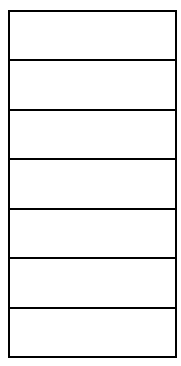

CONHECIMENTO DA LEGISLAÇÃO AMBIENTAL
1.PROIBIÇÃO DAS QUEIMAS
2.COLHEITA DE CANA CRUA
3.COLHEITA MECANIZADA
CUSTOS
EQUIPAMENTOS
ADAPTAÇÕES
RESTRIÇÕES EM ÁREAS COM DECLIVIDADE ALTA

\section{MARQUE AS TRÊS PRINCIPAIS}

PRÁTICAS DE CONSERVAÇÃO DO SOLO E DA ÁGUA

1.CULTIVO MÍNIMO 2.CORDÃO VEGETAL 3.TERRACEAMENTO 4.PLANTIO DIRETO 5.ADUBAÇÃO VERDE 6.COBERTURA MORTA 7.PROTEÇÃO DA FONTE DE ÁGUA 8.QUEBRA VENTO 9.ROTAÇÃO DE CULTURAS 10. CONSORCIAÇÃO

PRODUÇÃO X AMBIENTE

QUAL A QUESTÃO AMBIENTAL QUE MAIS PREOCUPA? SEM IMPOSIÇÃO DA LEGISLAÇÃO 1.QUALIDADE DA ÁGUA 2.EROSÃO DO SOLO 3. RESÍDUOS DE AGROTÓXICOS 4.DESMATAMENTO 5.PERDA DA BIODIVERSIDADE 6.BAIXA PRODUTIVIDADE 7.SUSTENTABILIDADE 8.QUEIMA DA PALHA 9.OUTRAS

SUSTENTABILIDADE LEMBRA:

1.ASPECTOS ECONÔMICOS 2.ASPECTOS DA PRODUÇÃO 3.ASPECTOS SOCIAIS 4.ASPECTOS DO AMBIENTE 5. ASPECTOS INSTITUCIONAIS/POLÍTICOS 6.TODOS 7.NENHUM 8.NÃO SABE

SUSTENTÁVEL: ECONÔMICAMENTE VIÁVEL, SOCIALMENTE JUSTO, PRODUTIVO, 
SEM DESTRUIR O AMBIENTE.

\begin{tabular}{|l||l|}
\hline QUANDO EXISTEM DÚVIDAS & \\
\hline PROCURA & \\
\hline ASSOCIAÇÃO / COOPERATIVA & \\
\cline { 2 - 3 } USINA / DESTILARIA & \\
CATI & \\
COPERSUCAR & \\
INDUSTRIAS VENDEDORAS DE PRODUTOS & \\
LIVROS / MANUAIS & \\
UNIVERSIDADES & \\
OUTROS & \\
\cline { 2 - 3 } &
\end{tabular}

ALTERNATIVAS PARA ÁREAS COM RESTRIÇÕES À MECANIZAÇÃO (SAF)

CONHECE O SISTEMA AGROFLORESTAL?

1.SIM 2.NÃO

JÁ VISITOU ALGÚM?

1.SIM 2.NÃO

CONHECE RESULTADOS DE PESQUISAS?

1.SIM 2.NÃO

VOCE ACHA QUE O SAF-CANA É SUSTENTÁVEL?

1.SIM 2.NÃO

HÁ INTERESSE EM TRANSFORMAR SUA PRODUÇÃO EM SAF-CANA? $1 . S I M$ 2.NÃO

COMO SERIAM OS PREÇOS DOS PRODUTOS EM SAF-CANA?

\section{ENTRAVES PARA A ADOÇÃO}

MARQUE AS TRES PRINCIPAIS EM ORDEM DECRESCENTE

TECNOLÓGICOS

PROBLEMAS CRÍTICOS PARA A PRODUÇÃO SAF-CANA:

1.FALTA DE CRÉDITO AGRÍCOLA ESPECÍFICO

2.FALTA DE RESULTADOS DE PESQUISA

3.DIFICULDADE PARA OBTENÇÃO DE INSUMOS

4.FALTA DE EXPERIÊNCIA

5.COMERCIALIZAÇÃO DA PRODUÇÃO

6.OBTENÇÃO DE INFORMAÇÕES E ASSISTÊNCIA TÉCNICA

7.FALTA DE MÃO DE OBRA ESPECIALIZADA

8.OUTROS

FATORES QUE FAZEM O SAF-CANA DE GRANDE POTENCIAL DE EXTENSÃO

1.HARMONIA COM A QUESTÃO AMBIENTAL

2.MELHORIA DA QUALIDADE DE VIDA

3.REDUÇÃO DO USO DE AGROTÓXICOS, ADUBOS SOLÚVEIS E ENERGIA

4.CONSERVAÇÃO DOS RECURSOS NATURAIS

5.MELHORES PREÇOS

6.NICHO DE MERCADO ESPECÍFICO DE GRANDE DEMANDA ATUAL

7.FORTALECE A AGRICULTURA FAMILIAR

8.FIXAÇÃO DA POPULAÇÃO NA ÁREA RURAL

9.MELHOR APROVEITAMENTO DA MÃO DE OBRA

10.CERTIFICAÇÀO DE ALIMENTOS 
11.OUTROS

\section{FORNECEDOR}

SE VOCE DECIDE POR PRODUZIR EM SAF-CANA, QUAIS AS RAZÕES QUE INFLUENCIARIAM SUA DECISÃO?

1.SAÚDE PESSOAL E DA FAMÍLIA 2.SAÚDE DO CONSUMIDOR 3.SAÚDE DA COMUNIDADE 4.CONVICÇÃO IDEOLÓGICA 5.RAZÕES ECONÔMICAS 6.POLÍTICA ATUAL 7.CONSERVAÇÃO DE REC. NATURAIS 8.MELHORAR PRODUTIVIDADE 9.OUTRAS

\section{DIFUSÃO}

INDIQUE AS FORMAS MAIS IMPORTANTES DE DIVULGAR INFORMAC̄ÕES, TECNOLOGIAS NOVAS, ADEQUAČÃO AMBIENTAL. 1.RÁDIO 2.JORNAL 3.TELEVISÃO 4.OUTROS FORNECEDORES 5.ASSOCIAÇÃO DE FORNECEDOR 6.PREFEITURA 7.CATI 8.CONSULTORIAS 9.MERCADO 10.AFOCAPI 11.SEMA/PMP 12.DRN-SM 13.VIDEO 14.CURSOS/PALESTRAS 15.INTERNET16.USINA

QUAIS OS ASPECTOS PRINCIPAIS PARA DIVULGAR ALTERNATIVAS DE PRODUÇÃO:(3) 1.TÉCNICAS DE PRODUÇÃO (VARIEDADES, CONTROLE DE PLANTAS DANINHAS, ETC.) 2.ECONÔMICOS (COMERCIALIZAÇÃO, PREÇOS, CUSTOS)

3.SOCIAS E CULTURAIS (CONSCIENTIZAÇÃO)

4.AMBIENTAIS (CONSERVAÇÃO DE RECURSOS NATURAIS)

5.INSTITUCIONAIS (CRÉDITOS, POLÍTICAS DE INCENTIVOS)

6.OUTROS

7.NÃO SABE

COMPLEXO AGRO-INDUSTRIAL ACHA QUE A USINA VAI SER PREJUDICADA SE VOCÊ DEIXAR DE PLANTAR CANA? SIM NÃO POR QUE?

COM ÁREAS RESTRITAS À COLHEITA MECANIZADA, HAVERÁ UMA REDUÇÃO DA PRODUÇÃO DE CANA?

CÓMO SOLUCIONAR ESTE PROBLEMA?

1. CONTINUAR COM CANA EM ÁREAS DECLIVOSAS

2. EXPANSÃO DE OUTRAS ÁREAS SEM RESTRIÇÕES

3. AUMENTAR PRODUTIVIDADE NAS ÁREAS MECANIZÁVEIS 
4. ADEQUAR AS ÁREAS PARA A COLHEITA MEC. COM SAF 5. NÃO SABE

RENTABILIDADE A LONGO PRAZO

SE DESTINAR AS ÁREAS COM RESTRIÇÕES À COLHEITA MECÂNICA AO SISTEMA AGROFLORESTAL COM CANA-DE-AÇÚCAR TERIA QUE CONSIDERAR:

1.INVESTIMENTO INICIAL

2.PLANEJAMENTO

3.MANEJO

4.TREINAMENTO

5.MERCADO
6.COMERCIALIZAÇÃO

7.MÃO-DE-OBRA ESPECIALIZADA

8.OUTROS 
APÊNDICE 3. Informativo resumido

\section{Sistemas de produção para áreas com restrições à} colheita mecanizadade cana-de-açúcar:

Os sistemas de produção agroflorestais para áreas inaptas à produção de cana-de-açúcar sem queima (SAF-Cana) devem atender às seguintes premissas:

- Adequação à legislação ambiental e que promovam efetivamente melhorias ao ambiente e à conservação do solo,

- Aceitação cultural pelos pequenos fornecedores tradicionais de cana-de-açúcar,

- Promoção da melhoria de oferta e fixação da mão-de-obra na cadeia produtiva,

- Receita operacional líquida similar àquela da cana-de-açúcar, atualmente situada em torno de US\$450,00/ha ano (AGRIANUAL, 1997), mercado seguro e possibilidade de beneficiamento e verticalização ou de comercialização local de seus produtos.

Foram identificadas culturas promissoras em termos de mercado e de adaptação ecológica, como a seringueira, o coco anão verde, os palmitos (pupunha, jussara e açaí) e os eucaliptos (Eucalyptus grandis, E. saligna e $E$. urophylla). Incluindo um estudo detalhado, para cada cultura, com quatro componentes: mercado, economia, adaptação ecológica e forma de combinação dentro do SAF-CANA.

Neste sistema as culturas perenes são distribuídas de forma a garantir a maior produtividade e proporcionar faixas permanentemente vegetadas que minimizam o impacto da erosão. Também, possibilita que a cana-de-açúcar seja implantada sem necessidade de terraceamento e com alinhamento paralelo dos sulcos de plantio. Assim, mesmo com declividade 
elevada é esperada maior eficiência da sua colheita mecanizada. A maior diversidade de culturas é outro fator benéfico, uma vez que há melhor distribuição da demanda por mão-de-obra durante o ano e possibilita fontes alternativas de renda.

Um exemplo hipotético de combinação de culturas acima descritas num SAF-CANA é o cultivo da cana-de-açúcar em faixas de 60 metros de largura, intercalada com faixas de linhas duplas de seringueira consorciada com palmitos ocupando uma faixa de 15 metros. Neste sistema, pela ausência de terraços na faixa de cana, a colheita mecanizada torna-se viável mesmo em terrenos com declividade mais acentuada.

O rendimento das culturas intercalares no SAF-CANA acima foi simulado pela equação proposta por Bernardes et al. (1997) e o rendimento da seringueira pelo modelo EMB-RUBBER (Bernardes et al., 1994). Considerandose o rendimento médio por hectare e o preço médio do produto de $80 \mathrm{t}$ de colmo e $\mathrm{R} \$ 12,00 / \mathrm{t} ; 1000 \mathrm{~kg}$ de borracha seca e $\mathrm{R} \$ 1,15 / \mathrm{kg}$; e $300 \mathrm{~kg}$ de palmito e $R \$ 3,00 / \mathrm{kg}$, para a cana-de-açúcar, seringueira e açaí, respectivamente verifica-se a possibilidade de obtenção ganhos de produtividade e rendimento econômico no sistema agroflorestal, conforme apresentado na tabela 1.

Tabela 1. Estimativa de produção, receita bruta e taxa de equivalente de terra em 10 hectares ocupados com o sistema de produção de cana-deaçúcar em monocultivo ou em sistema agroflorestal com seringueira, cana-de-açúcar e açaí.

\begin{tabular}{|c|c|c|c|c|c|}
\hline \multirow{2}{*}{$\begin{array}{l}\text { Sistema de } \\
\text { produção }\end{array}$} & \multicolumn{3}{|c|}{ Produção } & \multirow{2}{*}{$\begin{array}{l}\text { Receita bruta } \\
\qquad(\mathrm{R} \$)\end{array}$} & \multirow{2}{*}{$\begin{array}{c}\text { Taxa de } \\
\text { equivalente de } \\
\text { terra }\end{array}$} \\
\hline & $\begin{array}{c}\text { Cana } \\
(\mathrm{t})\end{array}$ & $\begin{array}{c}\text { Borracha } \\
(\mathrm{kg})\end{array}$ & Palmito (kg) & & \\
\hline $\begin{array}{l}\text { Cana-de- } \\
\text { açúcar }\end{array}$ & 800,0 & - & - & $9.600,00$ & 1,000 \\
\hline SAF-Cana & 578,5 & 240,0 & 18,6 & $9.757,80$ & 1,025 \\
\hline
\end{tabular}


Considerando a perda de solo nos dois sistemas de produção, sendo $19,7 \mathrm{t}$ de solo/ha.ano no sistema agroflorestal contra $24,4 \mathrm{t}$ de solo/ha.ano no monocultivo de cana.

Concluindo, os sistemas agroflorestais apresentam potencial para manter a atividade agrícola na região de Piracicaba, ocupando espaços principalmente em áreas com dificuldade para a colheita mecanizada da cana no modelo tecnológico atual dando maior sustentabilidade ao setor sucroalcooleiro. 